[Chem. Pharm. Bull.

35( 6 )2184-2195(1987)

\title{
Highly Stereoselective Total Synthesis of Methynolide, the Aglycon of the 12-Membered Macrolide Antibiotic Methymycin. I. Synthesis of a Prelog-Djerassi Lactone-Type Chiral Intermediate from D-Glucose ${ }^{1,2)}$
}

\author{
Yuji Oikawa, Tatsuyoshi Tanaka, Kiyoshi Horita, Ichio Noda, \\ Noriyuki NaKajima, NaOki Kakusawa, Tatsuo Hamada, \\ and OSAMU YONEMITSU* \\ Faculty of Pharmaceutical Sciences, Hokkaido University, \\ Kita-12, Nishi-6, Kita-ku, Sapporo 060, Japan
}

(Received September 19, 1986)

\begin{abstract}
For the highly stereoselective synthesis of methynolide (2), the aglycon of the 12-membered macrolide antibiotic methymycin (1), a Prelog-Djerassi lactone-type chiral intermediate (7a) bearing four chiral centers corresponding to the C-2, C-3, C-4, and C-6 positions was synthesized from D-glucose. In this synthesis, several stereocontrolled reactions such as hydroboration, catalytic hydrogenation, etc. were successfully applied. The utility of the 4-methoxybenzyl protecting group was also demonstrated.
\end{abstract}

Keywords - macrolide antibiotic; aglycon; methynolide; acyclic stereocontrol; hydroboration; catalytic hydrogenation; protecting group; stereoselective synthesis

Macrolide antibiotics with multiple chiral centers, owing to the presence of many substituents and functional groups, have received much recent synthetic attention because of their significant pharmacological and biological activities. ${ }^{3)}$ For the total synthesis of such complex compounds, new synthetic methodologies mainly consisting of means of stereochemical control in acyclic systems, selective use of suitable protecting groups, and efficient macro-cyclizations are primarily required.

As part of the synthetic effort directed towards polyketide-derived natural products, macrolide and polyether antibiotics, our attention has recently been focused on the chiral synthesis of some representative antibiotics, methymycin (1), ${ }^{4)}$ pikromycin, ${ }^{5)}$ erythromycin $\mathrm{A},{ }^{6)}$ tylosine, ${ }^{7)}$ iso-lasalocid $\mathrm{A},{ }^{8)}$ salinomycin, ${ }^{9)}$ etc., from $\mathrm{D}$-glucose as a chiral starting material.

In order to establish our synthetic methodology, which is widely applicable to the synthesis of complex antibiotics, and mainly consists of some acyclic stereocontrolled reactions and the use of benzyl-type protecting groups, ${ }^{10)}$ we first planned a highly stereoselective synthesis of methynolide $(2),{ }^{11}$ the aglycon of the 12 -membered macrolide antibiotic methymycin (1). Our retrosynthesis of $\mathbf{2}$, consisting of two routes, route a via the lactonization of the known seco-acid (3) and route b via the Wittig-Horner reaction of $\mathbf{4}$, is shown in Chart 1. Both segment $\mathrm{i}$ and segment ii for the synthesis of $\mathbf{3}$ or $\mathbf{4}$ were expected to be synthesized from a ulose (5). In the present paper, we report stereoselective syntheses of a Prelog-Djerassi lactone-type chiral intermediate (7a) from D-glucose via $\mathbf{5}$.

\section{Results and Discussion}

The Prelog-Djerassi lactonic acid (8), ${ }^{12)}$ corresponding to the C-1-C-7 segment of 2 , has 


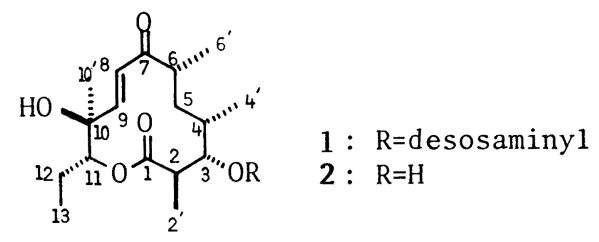

route a 8 route $b$

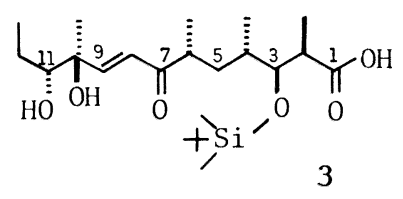

(RO)

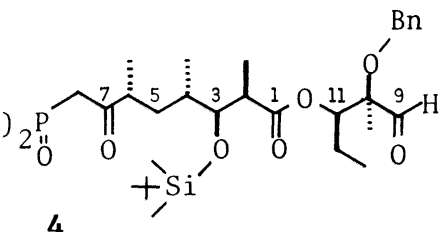

भु

$\sqrt{3}$

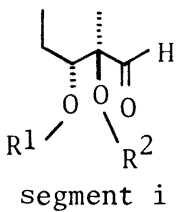

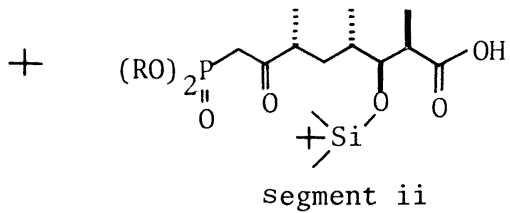<smiles>CCC1O[C@@H]2OC(C)(C)O[C@@H]2[C@]1(C)OCc1ccccc1</smiles><smiles>CC(C)O[C@H]1O[C@H](C(C)CO)[C@H](C)[C@H](C)[C@H]1O</smiles><smiles></smiles><smiles>C1=CC1</smiles><smiles>CC1(C)OCC(C2O[C@@H]3OC(C)(C)O[C@@H]3C2=O)O1</smiles>

5<smiles>CC(C(=O)O)C1OC(=O)[C@H](C)C[C@H]1C</smiles>

8

Chart 1

been a key compound for both the structure elucidation of $\mathbf{1}$ and subsequent synthetic efforts. The title compound (7a) is considered to be a more versatile synthetic equivalent of $\mathbf{8}$.

For the synthesis of $\mathbf{7 a}$, we first synthesized the key intermediate (19a), with three contiguous chiral centers corresponding to C-2-C-4 of 2 , from D-glucose via catalytic reduction or hydroboration of $\mathbf{1 2}, \mathbf{1 4}$, or 16 with acyclic stereocontrol (Chart 2). The known diol (9), ${ }^{13)}$ derived from 5, was converted to the epoxide (10) via a monotosylate. Reduction with lithium aluminium hydride (LAH) of $\mathbf{1 0}$ gave the secondary alcohol (11), which was oxidized with pyridinium chlorochromate (PCC) followed by the usual Wittig methylenation to give the olefin (12). On the other hand, nucleophilic ring opening of 10 with sodium 


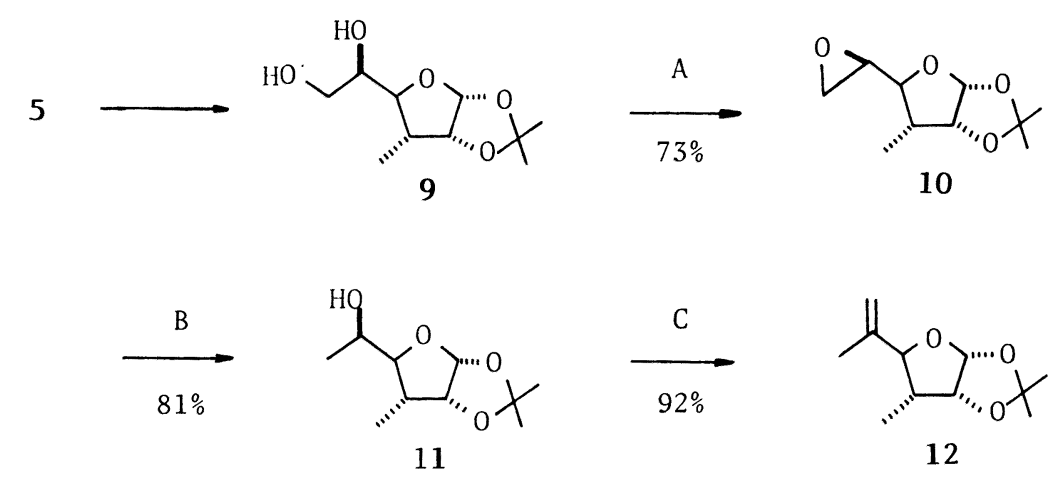

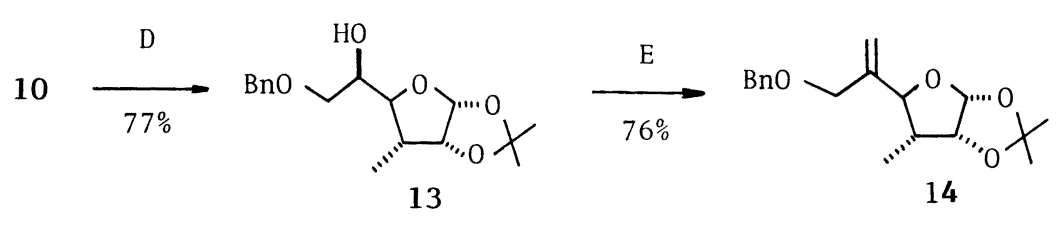

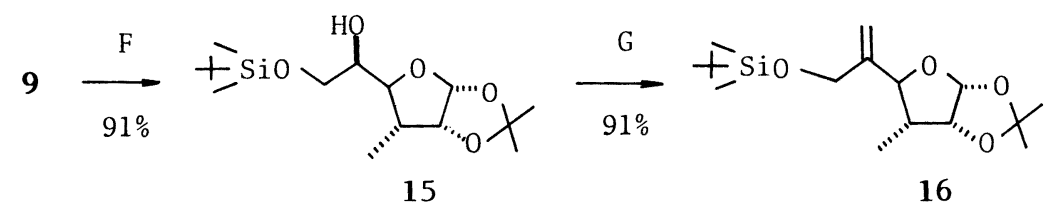<smiles>[R9]C[C@H](C)[C@H]1O[C@@H]2OC(C)(C)O[C@H]2[C@H]1C</smiles>

$\begin{array}{llll}\text { (A) 1) } \mathrm{TsCl} \text {, pyridine; 2) } \mathrm{K}_{2} \mathrm{CO}_{3}, \mathrm{MeOH} & \text { (B) } \mathrm{LAH}, \mathrm{Et}_{2} \mathrm{O} & \text { (C) 1) } \mathrm{PCC} \text {, molecular }\end{array}$ sieves, $\mathrm{CH}_{2} \mathrm{Cl}_{2}$;2) $\mathrm{Ph}_{3} \mathrm{P}=\mathrm{CH}_{2}$, THF (D) BnONa, DMSO-THF (E) 1) $\mathrm{PCC}$, molecular sieves, $\left.\mathrm{CH}_{2} \mathrm{Cl}_{2} ; 2\right) \mathrm{Ph}_{3} \mathrm{P}=\mathrm{CH}_{2}$, THF (F) TBDMSCl, imidazole, $\mathrm{CH}_{2} \mathrm{Cl}_{2}$ (G) 1) $(\mathrm{COCl})_{2}$, DMSO, $\mathrm{CH}_{2} \mathrm{Cl}_{2}, \mathrm{Et}_{3} \mathrm{~N},-50^{\circ} \mathrm{C}$; 2) $\mathrm{Ph}_{3} \mathrm{P}^{+} \mathrm{Me} \cdot \mathrm{Br}^{-}, n$ BuLi, THF, $0^{\circ} \mathrm{C}$

Chart 2

benzyloxide gave the hydroxybenzyl ether (13), which was similarly converted to the second olefin (14) in reasonable yield. The third olefin (16) was also easily synthesized from 9 via three conventional reactions, selective tert-butyldimethylsilyl (TBDMS) protection of the primary alcohol, Swern oxidation of the secondary alcohol and the final Wittig methylenation.

Hydrogenation of $\mathbf{1 4}$ over $10 \%$ palladium on charcoal (Pd-C) in ethyl acetate (EtOAc) gave a stereoisomeric mixture $(1.3: 1)$ with a slight excess of the desired isomer (17a). The ratio of $17 \mathbf{a}$ and $17 \mathbf{b}$ was improved to $4: 1$ by the use of $5 \%$ rhodium on alumina $\left(\mathrm{Rh}-\mathrm{Al}_{2} \mathrm{O}_{3}\right)$ catalyst, though this is still unsatisfactory (Table I). Almost no selectivity was observed in the hydrogenation of 16 over both $\mathrm{Pd}-\mathrm{C}$ and $\mathrm{Rh}-\mathrm{Al}_{2} \mathrm{O}_{3}$ catalysts; a ca. 1:1 mixture of 18a and 
TABLE I. Catalytic Hydrogenation and Hydroboration Results

\begin{tabular}{|c|c|c|c|}
\hline \multirow{2}{*}{ Substrate } & \multirow{2}{*}{ Conditions } & \multicolumn{2}{|c|}{ Product } \\
\hline & & Yield $(\%)$ & Ratio \\
\hline 14 & $10 \% \mathrm{Pd}-\mathrm{C}, \mathrm{H}_{2}$, EtOAc & $\mathbf{1 7 a}, \mathbf{b}$ & $1.3: 1$ \\
\hline 14 & $\mathrm{Rh}-\mathrm{Al}_{2} \mathrm{O}_{3}, \mathrm{H}_{2}, \mathrm{EtOH}$ & $\mathbf{1 7 a}, \mathbf{b}(100)$ & $4: 1$ \\
\hline 12 & $\mathrm{BH}_{3}, \mathrm{THF}$ & 19a, b (59) & $1: 6.8$ \\
\hline 14 & $\mathrm{BH}_{3}, \mathrm{THF}$ & 20a, b & $24: 1$ \\
\hline 16 & $\mathrm{BH}_{3}, \mathrm{THF}$ & 21a, b & $11: 1$ \\
\hline 22 & $\mathrm{BH}_{3}, \mathrm{THF}$ & 25a, b & $1: 6.0$ \\
\hline 23 & $\mathrm{BH}_{3}, \mathrm{THF}$ & 26a, b & $1: 1.8$ \\
\hline 24 & $\mathrm{BH}_{3}, \mathrm{THF}$ & 27a,b (69) & $1: 4$ \\
\hline
\end{tabular}

18b was obtained. Therefore, we turned our attention to hydroboration.

When 12 was treated with diborane, smooth hydroboration occurred to give a $6.8: 1$ mixture of 19b and 19a. Unfortunately, the major product was the undesired form. Recently, Still and Barrish ${ }^{14)}$ and Houk et al. ${ }^{15)}$ discussed transition state structures in the hydroboration of asymmetric allyl alcohol derivatives, and concluded that the conformation with the $\mathrm{C}-\mathrm{O}$ bond anti to the double bond was most favorable, as shown in Chart 3 . The result of hydroboration of $\mathbf{1 2}$ is consistent with their discussion, namely the $s i$-face attack in the M-1 structure (Chrat 3) with diborane was predominant. For the same reason, better stereoselectivities ( $r$-face attack of diborane) were obtained in the hydroboration of $\mathbf{1 4}$ and 16 to give mainly the desired products, 20a $(96: 4)$ and 21a $(92: 8)$, respectively (Table I). ${ }^{16)}$ Compounds 20a and 21a, without purification, were readily converted to the key intermediate (19a) by means of conventional reactions, tosylation, LAH reduction, etc. Benzyl protection of the primary alcohol of 19 a readily gave $17 \mathbf{a}$.

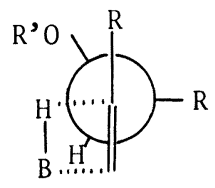

Still's model

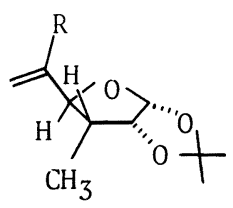

M-1

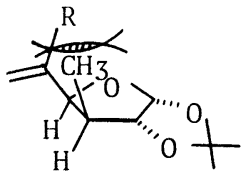

$\mathrm{M}-2$

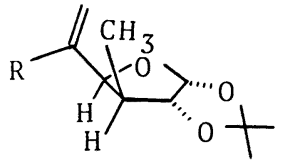

$\mathrm{M}-3$

$$
\begin{aligned}
& 12: \mathrm{R}=\mathrm{CH}_{3} \\
& 14: \mathrm{R}=\mathrm{CH}_{2} \mathrm{OBn} \\
& 16: \mathrm{R}=\mathrm{CH}_{2} \mathrm{OSi} 4
\end{aligned}
$$

Chart 3

The three contiguous chiral centers corresponding to C-5-C-7 of the title compound (7a) [i.e., to C-2 - C-4 of 2] were thus constructed, and the final chiral center at C-3 [C-6 of 2] was introduced stereoselectively by hydrogenation of $\alpha$-lactolide derivatives as follows (Chart 4).

The acetonide protection of $17 \mathbf{a}$ was removed with hydrochloric acid and the resultant lactol (28) was oxidized with sodium periodate to give the aldehyde (29). When 29 was treated with the sodium salt of dimethyl 1-methoxycarbonylethylphosphonate at $-90^{\circ} \mathrm{C}$, the WittigHorner reaction ${ }^{17)}$ proceeded quite smoothly to give the $(Z)-\alpha, \beta$-unsaturated ester $(9.6: 1$ 
stereoselectivity), which, without purification, was converted to the $\alpha, \beta$-unsaturated lactone (30) by treatment with methanolic potassium carbonate. Catalytic reduction of the double bond of $\mathbf{3 0}$ was expected to give a so-called Prelog-Djerassi lactone-type compound, but in order to increase the stereoselectivity of the reduction, $\mathbf{3 0}$ was converted to the anomerically pure $\alpha$-lactolide (31) via reduction with diisobutylaluminum hydride (DIBAH) followed by isopropyl protection of the resultant lactol. ${ }^{18)}$

When 31 was hydrogenated over $10 \% \mathrm{Pd}-\mathrm{C}$ in EtOAc at $0{ }^{\circ} \mathrm{C}, 32$ was obtained in high yield, though the stereoselectivity $(6: 1)$ was still unsatisfactory. Debenzylation of 32, without purification, over Raney nickel $\left.(\mathrm{Ni}) \mathrm{W}-2^{19}\right)$ readily gave the title compound (7a) after chromatographic purification. When 31 was reduced over $\mathrm{Rh}-\mathrm{Al}_{2} \mathrm{O}_{3}$ in ether, concomitant saturation of the benzyl group was unavoidable. After several examinations of substrates and catalysts in order to increase the stereoselectivity, an excellent result was obtained in the reduction of 38, which was synthesized from the key intermediate (19a) via 33-37 by a method virtually identical with that described for 31, forllowed by removal of the 4methoxybenzyl (MPM) protection of 37 with 2,3-dichloro-5,6-dicyanobenzoquinone (DDQ). The deprotection was smoothly carried out by a slight modification of the usual method, ${ }^{10)}$ namely in the presence of isopropanol, in good yield. ${ }^{19)}$ Hydrogenation of 38 over $\mathrm{Rh}-\mathrm{Al}_{2} \mathrm{O}_{3}$ in ether gave the desired $7 \mathbf{a}$ with excellent stereoselectivity $(25: 1)$ in quantitative yield. Compound $7 \mathbf{a}$ has all the chiral centers required for segment ii, whose synthesis will be<smiles>[R6]C[C@H](C)[C@H]1O[C@@H]2OC(C)(C)O[C@@H]2[C@H]1C</smiles>

17a: $\mathrm{R}=\mathrm{Bn}$ 33: $\mathrm{R}=\mathrm{MPM}$<smiles>[R]C[C@H](C)[C@H](OC([2H])=O)[C@@H](C)C=O</smiles>

29: $\mathrm{R}=\mathrm{Bn}(94 \%)$

35: $R=\operatorname{MPM}(93 \%)$<smiles>[R6]C[C@H](C)[C@H]1O[C@@H](OC(C)C)C(C)=C[C@H]1C</smiles>

31: $\mathrm{R}=\mathrm{Bn}(96 \%)$

37: $\mathrm{R}=\mathrm{MPM}(98 \%)$

38: $\mathrm{R}=\mathrm{H}(78 \%)-\mathrm{L}$
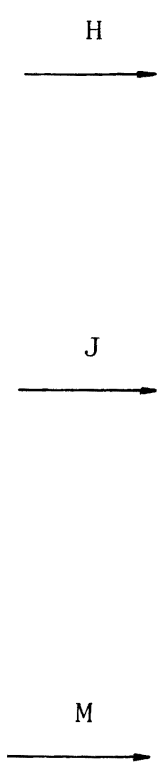

(H) $4 \mathrm{~N} \mathrm{HCl}$, THF or dioxane, $40-45^{\circ} \mathrm{C}$ (I) $\mathrm{NaIO}_{4}, \mathrm{MeOH}-\mathrm{H}_{2} \mathrm{O}, 0^{\circ} \mathrm{C}$ or $\mathrm{Pb}(\mathrm{OAc})_{4}$, benzene (J) 1) $\left.(\mathrm{MeO})_{2} \mathrm{POCH}(\mathrm{Me}) \mathrm{CO}_{2} \mathrm{Me}, \mathrm{NaH}, \mathrm{THF},-80 \rightarrow 8^{\circ} \mathrm{C} ; 2\right)$ $\mathrm{K}_{2} \mathrm{CO}_{3}$, MeOH (K) 1) DIBAH, toluene, $-80^{\circ} \mathrm{C}$; 2) CSA, iso-PrOH (L) DDQ, $\mathrm{CH}_{2} \mathrm{Cl}_{2}-\mathrm{H}_{2} \mathrm{O}$-iso-PrOH (M) a: 31 $\rightarrow$ 7a; 1) $\mathrm{Pd}-\mathrm{C}, \mathrm{H}_{2}$, EtOAc; 2) Raney Ni (W-2), $\mathrm{H}_{2}, \mathrm{EtOH}$ b: 38 $\rightarrow 7 \mathbf{a} ; \mathrm{Rh}-\mathrm{Al}_{2} \mathrm{O}_{3}, \mathrm{H}_{2}, \mathrm{Et}_{2} \mathrm{O}$<smiles>[R6]C[C@H](C)[C@H]1O[C@H](O)[C@@H](O)[C@H]1C</smiles>

28: $\mathrm{R}=\mathrm{Bn}(83 \%)$

34: $\mathrm{R}=\mathrm{MPM}(78 \%)$<smiles>[R6]C[C@H](C)[C@H]1OC(=O)C(C)=C[C@H]1C</smiles>

30: $\mathrm{R}=\mathrm{Bn}(92 \%)$

36: $R=\operatorname{MPM}(81 \%)$<smiles>[R]CC(C)C1OC(OC(C)C)[C@H](C)C[C@H]1C</smiles>

32: $\mathrm{R}=\mathrm{Bn}$

$7 a: R=H \quad(99 \%)$
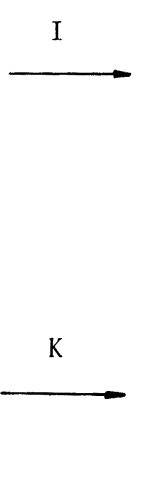

$7 b$ 
described in the following paper.

\section{Experimental}

Unless otherwise noted, physical data were measured as follows. Optical rotations were measured with a JASCO DIP-4 digital polarimeter. Proton nuclear magnetic resonance $\left({ }^{1} \mathrm{H}-\mathrm{NMR}\right)$ spectra were recorded on a JEOL FX-200 $(200 \mathrm{MHz})$ or JEOL JNM GX-270 (270 MHz) instrument. Mass spectra (MS) were taken on a JEOL JMS D-300 or JEOL JMS-01 SG spectrometer. Infrared (IR) spectra were recorded on a JASCO IR-2 spectrometer.

5,6-Anhydro-3-deoxy-1,2- $O$-isopropylidene-3- $C$-methyl- $\alpha$-D-allofuranose (10) - $p$-Toluenesulfonyl chloride $(\mathrm{TsCl})(4.91 \mathrm{~g}, 25.7 \mathrm{mmol})$ was added portionwise to a stirred solution of $\left.9^{13}\right)(5.61 \mathrm{~g}, 25.7 \mathrm{mmol})$ in pyridine $(36 \mathrm{ml})$ over a period of $7 \mathrm{~h}$. After an additional $17 \mathrm{~h}$, the reaction mixture was poured into ice-water $(150 \mathrm{ml})$ and extracted with $\mathrm{CH}_{2} \mathrm{Cl}_{2}$. The extract was washed with $2 \mathrm{~N} \mathrm{HCl}$, brine and $5 \% \mathrm{NaHCO}_{3}$, dried $\left(\mathrm{Na}_{2} \mathrm{SO}_{4}\right)$, and evaporated in vacuo. The residue was dissolved in $\mathrm{MeOH}(120 \mathrm{ml})$, and treated with $\mathrm{K}_{2} \mathrm{CO}_{3}(4 \mathrm{~g})$ at room temperature for $40 \mathrm{~min}$. The reaction mixture was evaporated in vacuo, and the residue was extracted with $\mathrm{CH}_{2} \mathrm{Cl}_{2}$. The extract was washed with brine, dried $\left(\mathrm{Na}_{2} \mathrm{SO}_{4}\right)$, and evaporated in vacuo to leave an oil, which was chromatographed on a silica gel column with hexane-EtOAc $(4: 1)$ to afford 10 as a colorless oil $(3.78 \mathrm{~g}, 73.4 \%) .{ }^{1} \mathrm{H}-\mathrm{NMR}\left(\mathrm{CDCl}_{3}\right) \delta: 1.17(3 \mathrm{H}, \mathrm{d}$, $J=7 \mathrm{~Hz}), 1.33(3 \mathrm{H}, \mathrm{s}), 1.50(3 \mathrm{H}, \mathrm{s}), 2.03(1 \mathrm{H}, \mathrm{ddq}, J=4.5,10,7 \mathrm{~Hz}), 2.68(1 \mathrm{H}, \mathrm{dd}, J=2.5,5 \mathrm{~Hz}), 2.78(1 \mathrm{H}, \mathrm{dd}, J=4$, $5 \mathrm{~Hz}), 2.9 .2(1 \mathrm{H}$, ddd, $J=2.5,4,6 \mathrm{~Hz}), 3.51(1 \mathrm{H}, \mathrm{dd}, J=6,10 \mathrm{~Hz}), 4.57(1 \mathrm{H}, \mathrm{dd}, J=3.5,4.5 \mathrm{~Hz}), 5.81(1 \mathrm{H}, \mathrm{d}, J=$ $3.5 \mathrm{~Hz}$ ). MS $m / \mathrm{z}$ (relative intensity): $185\left(\mathrm{M}^{+}-15,50\right), 157(10), 99(20), 59(56), 43$ (100). Exact MS $m / z$ Calcd for $\mathrm{C}_{9} \mathrm{H}_{13} \mathrm{O}_{4}\left(\mathrm{M}^{+}-15\right): 185.0814$. Found: 185.0811 .

3,6-Dideoxy-1,2- $\boldsymbol{O}$-isopropylidene-3- $\boldsymbol{C}$-methyl- $\boldsymbol{\alpha}$-D-allofuranose (11)_-A solution of $\mathbf{1 0}(6.78 \mathrm{~g}, 33.9 \mathrm{mmol})$ in $\mathrm{Et}_{2} \mathrm{O}(17 \mathrm{ml})$ was added dropwise to a stirred ice-cold suspension of $\mathrm{LAH}(0.845 \mathrm{~g}, 22.2 \mathrm{mmol})$ in $\mathrm{Et}_{2} \mathrm{O}(63 \mathrm{ml})$. The mixture was stirred for $5 \mathrm{~h}$ at $0{ }^{\circ} \mathrm{C}$ and then $1 \mathrm{~h}$ at room temperature. Usual work-up gave an oil, which was chromatographed on a silica gel column with hexane-EtOAc $(3: 2)$ to afford 11 as a colorless oil $(5.55 \mathrm{~g}, 81 \%) .{ }^{1} \mathrm{H}$ NMR $\left(\mathrm{CDCl}_{3}\right) \delta: 1.14(3 \mathrm{H}, \mathrm{d}, J=7 \mathrm{~Hz}), 1.21(3 \mathrm{H}, \mathrm{d}, J=7 \mathrm{~Hz}), 1.34(3 \mathrm{H}, \mathrm{s}), 1.52(3 \mathrm{H}, \mathrm{s}), 1.99(1 \mathrm{H}, \mathrm{d}, J=4 \mathrm{~Hz}), 2.10$ $(1 \mathrm{H}, \mathrm{ddq}, J=5,10,7 \mathrm{~Hz}), 3.80(1 \mathrm{H}, \mathrm{dd}, J=3,10 \mathrm{~Hz}), 4.20(1 \mathrm{H}, \mathrm{ddq}, J=3,4,7 \mathrm{~Hz}), 4.56(1 \mathrm{H}, \mathrm{dd}, J=4,5 \mathrm{~Hz}), 5.77$ (1H, d, $J=4 \mathrm{~Hz}$ ). MS $m / z$ (relative intensity): $187\left(\mathrm{M}^{+}-15,30\right), 157$ (48), 99 (77), 71 (53), 59 (93), 43 (100). Exact MS $m / z$ Calcd for $\mathrm{C}_{9} \mathrm{H}_{15} \mathrm{O}_{4}\left(\mathrm{M}^{+}-15\right): 187.0970$. Found: 187.0982 .

3,5,6-Trideoxy-1,2-O-isopropylidene-3- $C$-methyl-5-methylene- $\alpha$-D-ribo-hexofuranose (12)_-A solution of 11 $(0.554 \mathrm{~g}, 2.52 \mathrm{mmol})$ and PCC $(1.20 \mathrm{~g}, 5.57 \mathrm{mmol})$ in $\mathrm{CH}_{2} \mathrm{Cl}_{2}(35 \mathrm{ml})$ with powdered $3 \AA$ molecular sieves $(4.2 \mathrm{~g})$ was stirred for $6 \mathrm{~h}$ at room temperature. After removal of insoluble materials by filtration, the filtrate was evaporated in vacuo and the residue was extracted with ether. The extract was purified by passage through a silica gel column with ether to give the ketone as a colorless oil $(0.463 \mathrm{~g}, 92 \%)$. IR $v_{\max } \mathrm{cm}^{-1}: 1720 .{ }^{1} \mathrm{H}-\mathrm{NMR}\left(\mathrm{CDCl}_{3}\right) \delta: 1.16(3 \mathrm{H}, \mathrm{d}, J=$ $7 \mathrm{~Hz}), 1.35(3 \mathrm{H}, \mathrm{s}), 1.51(3 \mathrm{H}, \mathrm{s}), 2.00(1 \mathrm{H}, \mathrm{ddq}, J=5,11,7 \mathrm{~Hz}), 4.08(1 \mathrm{H}, \mathrm{d}, J=11 \mathrm{~Hz}), 4.58(1 \mathrm{H}, \mathrm{dd}, J=3,5 \mathrm{~Hz}), 5.91$ (1H, d, $J=3 \mathrm{~Hz}$ ). MS $m / z$ (relative intensity): $185\left(\mathrm{M}^{+}-15,12\right), 157$ (55), 99 (58), 85 (18), 71 (50), 59 (80), 43 (100). Exact MS $m / z$ Calcd for $\mathrm{C}_{9} \mathrm{H}_{13} \mathrm{O}_{4}\left(\mathrm{M}^{+}-15\right)$ : 185.0814 . Found: 185.0812 .

A tetrahydrofuran (THF) solution $(1 \mathrm{ml})$ of the above ketone $(0.290 \mathrm{~g}, 1.45 \mathrm{mmol})$ was added dropwise to a stirred solution of methylenetriphenylphosphorane, prepared from $\mathrm{NaH}(0.104 \mathrm{~g}, 4.33 \mathrm{mmol})$ in dimethylsulfoxide (DMSO) and methyltriphenylphosphonium bromide $(1.65 \mathrm{~g}, 4.62 \mathrm{mmol})$, at $18^{\circ} \mathrm{C}$. After $2 \mathrm{~h}$, the reaction mixture was poured into ice-cold saturated $\mathrm{NH}_{4} \mathrm{Cl}$ and extracted with $\mathrm{CH}_{2} \mathrm{Cl}_{2}$. The extract was washed with water, dried, and evaporated in vacuo to leave an oil, which was chromatographed on a silica gel column with hexane-EtOAc $(3: 2)$ as the eluent to afford 12 as a colorless oil $(0.287 \mathrm{~g}, 100 \%) .{ }^{1} \mathrm{H}-\mathrm{NMR}\left(\mathrm{CDCl}_{3}\right) \delta: 1.01(3 \mathrm{H}, \mathrm{d}, J=7 \mathrm{~Hz}), 1.34(3 \mathrm{H}, \mathrm{s}), 1.53$ $(3 \mathrm{H}, \mathrm{s}), 1.71(3 \mathrm{H}, \mathrm{s}), 1.88(1 \mathrm{H}, \mathrm{ddq}, J=4,0.5,7 \mathrm{~Hz}), 4.12(1 \mathrm{H}, \mathrm{d}, J=10.5 \mathrm{~Hz}), 4.57(1 \mathrm{H}, \mathrm{dd}, J=3.5,4.0 \mathrm{~Hz}), 4.93-5.0$ $(2 \mathrm{H}, \mathrm{m}), 5.83\left(1 \mathrm{H}, \mathrm{d}, J=3.5 \mathrm{~Hz}\right.$ ). MS $m / z$ (relative intensity): $198\left(\mathrm{M}^{+}, 4.7\right), 183(25), 140(12), 128(15), 99$ (18), 95 (27), 59 (100). Exact MS $m / z$ Calcd for $\mathrm{C}_{11} \mathrm{H}_{18} \mathrm{O}_{3}\left(\mathrm{M}^{+}\right)$: 198.1256. Found: 198.1251.

6-O-Benzyl-3-deoxy-1,2- $O$-isopropylidene-3- $C$-methyl- $\alpha$-D-allofuranose (13)-A THF solution (6 ml) of 10 $(5.27 \mathrm{~g}, 26.3 \mathrm{mmol})$ was added to a stirred solution of sodium benzyloxide, prepared from $\mathrm{NaH}(0.942 \mathrm{~g}, 39.25 \mathrm{mmol})$ and benzyl alcohol $(4.24 \mathrm{~g}, 39.35 \mathrm{mmol})$ in DMSO $(13 \mathrm{ml})$ and THF $(6 \mathrm{ml})$, at room temperature. After $13 \mathrm{~h}$, the reaction mixture was poured into cold saturated $\mathrm{NH}_{4} \mathrm{Cl}$, and extracted with $\mathrm{CH}_{2} \mathrm{Cl}_{2}$. The extract was washed with water, dried $\left(\mathrm{Na}_{2} \mathrm{SO}_{4}\right)$, and evaporated in vacuo. The residue was chromatographed on a silica gel column with hexane-EtOAc $(4: 1)$ as the eluent to afford 13 as a colorless oil $(6.274 \mathrm{~g}, 77 \%)[\alpha]_{\mathrm{D}}^{17}+19^{\circ}\left(c=1.40, \mathrm{CHCl}_{3}\right) .{ }^{1} \mathrm{H}-\mathrm{NMR}$ $\left(\mathrm{CDCl}_{3}\right) \delta: 1.16(3 \mathrm{H}, \mathrm{d}, J=7 \mathrm{~Hz}), 1.33(3 \mathrm{H}, \mathrm{s}) 1.51(3 \mathrm{H}, \mathrm{s}), 2.08(1 \mathrm{H}, \mathrm{ddq}, J=5,10,7 \mathrm{~Hz}), 2.42(1 \mathrm{H}, \mathrm{d}, J=4 \mathrm{~Hz}), 3.54$ $(1 \mathrm{H}, \mathrm{dd}, J=7,10 \mathrm{~Hz}), 3.65(1 \mathrm{H}, \mathrm{dd}, J=3,10 \mathrm{~Hz}), 3.81(1 \mathrm{H}, \mathrm{dd}, J=5,10 \mathrm{~Hz}), 3.82(1 \mathrm{H}, \mathrm{dddd}, J=3,4,5,7 \mathrm{~Hz}), 4.53$ $(1 \mathrm{H}, \mathrm{d}, J=12 \mathrm{~Hz}), 4.54(1 \mathrm{H}, \mathrm{dd}, J=4,5 \mathrm{~Hz}), 4,58(1 \mathrm{H}, \mathrm{d}, J=12 \mathrm{~Hz}), 5.75(1 \mathrm{H}, \mathrm{d}, J=4 \mathrm{~Hz}), 7.34(5 \mathrm{H}, \mathrm{s}) . \mathrm{MS} m / z$ (relative intensity): $308\left(\mathrm{M}^{+}, 3\right), 293(6), 250(10), 157$ (30), 99 (100). Exact $\mathrm{MS} \mathrm{m} / z$ Calcd for $\mathrm{C}_{17} \mathrm{H}_{24} \mathrm{O}_{5}\left(\mathrm{M}^{+}\right)$: 308.1625. Found: 308.1621 .

6-O-Benzyl-3,5-dideoxy-1,2- $O$-isopropylidene-3- $C$-methyl-5-methylene- $\alpha$-D-ribo-hexofuranose (14)-PCC $(3.80 \mathrm{~g}, 17.6 \mathrm{mmol})$ and powdered molecular sieves $3 \AA(12 \mathrm{~g})$ were added to a stirred solution of $13(2.371 \mathrm{~g}$, $7.70 \mathrm{mmol})$ in $\mathrm{CH}_{2} \mathrm{Cl}_{2}(80 \mathrm{ml})$ at room temperature. After $24 \mathrm{~h}$, the reaction mixture was filtered, and the filtrate was 
concentrated in vacuo to leave an oil, which was chromatographed on a silica gel column with hexane-EtOAc $(3: 2)$ as the eluent to afford the ketone as a colorless oil $(2.09 \mathrm{~g}, 89 \%)$. IR $v_{\max }^{\text {neat }} \mathrm{cm}^{-1}: 1720 .{ }^{1} \mathrm{H}-\mathrm{NMR}\left(\mathrm{CDCl}_{3}\right) \delta: 1.20(3 \mathrm{H}, \mathrm{d}$, $J=7 \mathrm{~Hz}), 2.33(3 \mathrm{H}, \mathrm{s}), 1.50(3 \mathrm{H}, \mathrm{s}), 1.80-2.24(1 \mathrm{H}, \mathrm{m}), 4.18(2 \mathrm{H}, \mathrm{d}, J=11 \mathrm{~Hz}), 4.42(2 \mathrm{H}, \mathrm{s}), 4.54(1 \mathrm{H}, \mathrm{dd}, J=3.5$, $4.5 \mathrm{~Hz}), 4.61(1 \mathrm{H}, \mathrm{s}), 5.83(1 \mathrm{H}, \mathrm{d}, J=3.5 \mathrm{~Hz}), 7.33(5 \mathrm{H}, \mathrm{s}) . \mathrm{MS} m / z$ (relative intensity): $306\left(\mathrm{M}^{+}, 0.25\right), 291(1.6), 278$ (2.0), 277 (2.6), 200 (6.1), $157(50), 120$ (15), 105 (20), 99 (75), 91 (100). Exact MS m/z Calcd for $\mathrm{C}_{17} \mathrm{H}_{22} \mathrm{O}_{5}\left(\mathrm{M}^{+}\right)$: 306.1467. Found: 306.1474

A $1.85 \mathrm{M}$ solution of $\mathrm{BuLi}$ in hexane $(0.35 \mathrm{ml}, 0.56 \mathrm{mmol})$ was added to a suspension of methyltriphenylphosphonium bromide $(218 \mathrm{mg}, 0.62 \mathrm{mmol})$ in THF $(1 \mathrm{ml})$ at $-10^{\circ} \mathrm{C}$, and the mixture was stirred for an additional $1 \mathrm{~h}$ at $-10 \mathrm{C}$ and then for $2 \mathrm{~h}$ at room temperature. Next, a solution of the ketone $(85 \mathrm{mg}, 0.28 \mathrm{mmol})$ in THF $(0.5 \mathrm{ml})$ was added dropwise at $-10 \mathrm{C}$ and the reaction mixture was stirred overnight at room temperature, then poured into brine, and extracted with ether. The extract was dried $\left(\mathrm{MgSO}_{4}\right)$ and evaporated in vacuo. The residue was chromatographed on a silica gel column with hexane-EtOAc $(6: 1)$ as the eluant to give $\mathbf{1 4}$ as a colorless oil (72 mg, $85 \%) \cdot[\alpha]_{\mathrm{D}}^{17}+15.0^{\circ}\left(c=3.0, \mathrm{CHCl}_{3}\right) \cdot{ }^{1} \mathrm{H}-\mathrm{NMR}\left(\mathrm{CDCl}_{3}\right) \delta: 1.04(3 \mathrm{H}, \mathrm{d}, J=7 \mathrm{~Hz}), 1.33(3 \mathrm{H}, \mathrm{s}), 1.52(3 \mathrm{H}, \mathrm{s}), 2.05(1 \mathrm{H}$, $\mathrm{ddq}, J=5,10,7 \mathrm{~Hz}), 4.01(1 \mathrm{H}, \mathrm{d}, J=13.5 \mathrm{~Hz}), 4.13(1 \mathrm{H}, \mathrm{d}, J=13.5 \mathrm{~Hz}), 4.23(1 \mathrm{H}, \mathrm{d}, J=10 \mathrm{~Hz}), 4.48(1 \mathrm{H}, \mathrm{d}, J=$ $12 \mathrm{~Hz}), 4.54(1 \mathrm{H}, \mathrm{dd}, J=3.5,5 \mathrm{~Hz}), 4.55(1 \mathrm{H}, \mathrm{d}, J=12 \mathrm{~Hz}), 5.24(1 \mathrm{H}, \mathrm{s}), 5.34(1 \mathrm{H}, \mathrm{dd}, J=1.5,3 \mathrm{~Hz}), 5.79(1 \mathrm{H}, \mathrm{d}, J=$ $3.5 \mathrm{~Hz}), 7.33(5 \mathrm{H}, \mathrm{s})$. MS $m / z$ (relative intensity): $289\left(\mathrm{M}^{+}-15,4.0\right), 198$ (14), $183(27), 140(9.5), 107$ (25), 91 (100). Exact MS $m / z$ Calcd for $\mathrm{C}_{17} \mathrm{H}_{21} \mathrm{O}_{4}\left(\mathrm{M}^{+}-15\right): 289.1440$. Found: 289.1441 .

6-O-tert-Butyldimethylsilyl-3-deoxy-1,2-O -isopropylidene-3- $\boldsymbol{C}$-methyl- $\alpha$-D-allofuranose (15)—-tert-Butyldimethylsilyl chloride $(8.15 \mathrm{~g}, 54.0 \mathrm{mmol})$ in $\mathrm{CH}_{2} \mathrm{Cl}_{2}(10 \mathrm{ml})$ was added dropwise to a stirred solution of $9(11.68 \mathrm{~g}$, $54.0 \mathrm{mmol})$ and imidazole $(9.2 \mathrm{~g}, 135 \mathrm{mmol})$ in $\mathrm{CH}_{2} \mathrm{Cl}_{2}(60 \mathrm{ml})$ in an ice bath. After $1 \mathrm{~h}$ at room temperature, the reaction mixture was poured into saturated $\mathrm{NH}_{4} \mathrm{Cl}$. The organic layer was washed with brine, dried $\left(\mathrm{MgSO}_{4}\right)$, and evaporated in vacuo to leave an oil, which was chromatographed on a silica gel column with hexane-EtOAc $(20: 1)$ to give 15 as a colorless oil $(16.1 \mathrm{~g}, 90.6 \%) .{ }^{1} \mathrm{H}-\mathrm{NMR}\left(\mathrm{CDCl}_{3}\right) \delta: 0.08(6 \mathrm{H}, \mathrm{s}), 0.90(9 \mathrm{H}, \mathrm{s}), 1.20(3 \mathrm{H}, \mathrm{d}, J=7 \mathrm{~Hz}), 1.33$ $(3 \mathrm{H}, \mathrm{s}), 1.51(3 \mathrm{H}, \mathrm{s}), 1.90-2.08(1 \mathrm{H}, \mathrm{m}), 2.54(1 \mathrm{H}, \mathrm{br} \mathrm{s}), 3.60-3.82(4 \mathrm{H}, \mathrm{m}), 4.54(1 \mathrm{H}, \mathrm{dd}, J=3.5,4.5 \mathrm{~Hz}), 5.75(1 \mathrm{H}$, $\mathrm{d}, J=3.5 \mathrm{~Hz}$ ). MS $m / z$ (relative intensity): $317\left(\mathrm{M}^{+}-15,11\right), 275(7), 217(46), 190(32), 157(22), 117(86), 99(51), 89$ (33), 75 (100). Exact MS $m / z$ Calcd for $\mathrm{C}_{15} \mathrm{H}_{29} \mathrm{O}_{5} \mathrm{Si}\left(\mathrm{M}^{+}-15\right)$ : 317.1784 . Found: 317.1777 .

6- $O$-tert-Butyldimethylsilyl-3,5-dideoxy-1,2- $O$-isopropylidene-3- $C$-methyl-5-methylene- $\alpha$-D-ribo-hexofuranose (16) - DMSO $(8 \mathrm{ml})$ was added dropwise to a stirred solution of oxalyl chloride $(3.44 \mathrm{ml}, 39.7 \mathrm{mmol})$ in $\mathrm{CH}_{2} \mathrm{Cl}_{2}$ $(100 \mathrm{ml})$ at a temperature below $-50^{\circ} \mathrm{C}$. After $5 \mathrm{~min}$, a solution of $15(11.0 \mathrm{~g}, 33.1 \mathrm{mmol})$ in $\mathrm{CH}_{2} \mathrm{Cl}_{2}(20 \mathrm{ml})$ was added. After $2 \mathrm{~h}$ at $-50^{\circ} \mathrm{C}$, the mixture was treated with $\mathrm{NEt}_{3}(24 \mathrm{ml})$, then allowed to warm to room temperature, and poured into brine. The aqueous layer was extracted with $\mathrm{CH}_{2} \mathrm{Cl}_{2}$, and the combined organic extracts were dried $\left(\mathrm{MgSO}_{4}\right)$. Evaporation of the solvent in vacuo left an oil, which was chromatographed on a silica gel column with EtOAc-hexane $(1: 25)$ to give 6-O-tert-butyldimethylsilyl-3-deoxy-3-C-methyl- $\alpha$-D-ribo-hexofuranos-5-ulose $(10.5 \mathrm{~g}$, $96 \%)$ as a colorless oil. IR $v_{\max }^{\text {neat }} \mathrm{cm}^{-1}: 1730 .{ }^{1} \mathrm{H}-\mathrm{NMR}\left(\mathrm{CDCl}_{3}\right) \delta: 0.08(3 \mathrm{H}, \mathrm{s}), 0.09(3 \mathrm{H}, \mathrm{s}), 0.91(9 \mathrm{H}, \mathrm{s}), 1.20(3 \mathrm{H}, \mathrm{d}$, $J=7.0 \mathrm{~Hz}), 1.34(3 \mathrm{H}, \mathrm{s}), 1.51(3 \mathrm{H}, \mathrm{s}), 1.91-2.10(1 \mathrm{H}, \mathrm{m}), 4.23(1 \mathrm{H}, \mathrm{d}, J=10.5 \mathrm{~Hz}), 4.25-4.59(3 \mathrm{H}, \mathrm{m}), 5.88(1 \mathrm{H}, \mathrm{d}$, $J=3.5 \mathrm{~Hz}$ ). MS $m / z$ (relative intensity): $315\left(\mathrm{M}^{+}-15,6\right), 273(1.5), 215(5), 157$ (5), 117 (100).

A $1.6 \mathrm{M}$ hexane solution of $n-\mathrm{BuLi}$ in hexane $(254 \mathrm{ml}, 0.407 \mathrm{~mol})$ was added dropwise to a stirred suspension of methyltriphenylphosphonium bromide $(70 \mathrm{~g}, 0.478 \mathrm{~mol})$ in THF $(2.5 \mathrm{l})$ at a temperature below $0{ }^{\circ} \mathrm{C}$ in an ice-salt bath. The reaction mixture was stirred for $5 \mathrm{~h}$ at room temperature, then cooled again to below $0{ }^{\circ} \mathrm{C}$, and the above ulose $(58.4 \mathrm{~g}, 0.177 \mathrm{~mol})$ in THF was added. The mixture was stirred for $16 \mathrm{~h}$, poured into saturated $\mathrm{NH}_{4} \mathrm{Cl}$, and extracted with $\mathrm{CH}_{2} \mathrm{Cl}_{2}$. The extract was washed with brine, and concentrated in vacuo to leave an oil, which was extracted with hexane. The hexane extract was evaporated in vacuo and the residue was chromatographed on a silica gel column. Elution with benzene-hexane $(4: 1)$ gave triphenylphosphine and further elution with EtOAc afforded $\mathbf{1 6}$ as a colorless oil $(54.9 \mathrm{~g}, 95 \%) \cdot[\alpha]_{\mathrm{D}}^{20}+27.0^{\circ}(c=0.98, \mathrm{MeOH})$. IR $v_{\max }^{\text {neat }} \mathrm{cm}^{-1}: 1660 .{ }^{1} \mathrm{H}-\mathrm{NMR}\left(\mathrm{CDCl}_{3}\right) \delta: 0.07(6 \mathrm{H}, \mathrm{s}), 0.91$ $(9 \mathrm{H}, \mathrm{s}), 1.04(3 \mathrm{H}, \mathrm{d}, J=7.0 \mathrm{~Hz}), 1.34(3 \mathrm{H}, \mathrm{s}), 1.52(3 \mathrm{H}, \mathrm{s}), 1.92-2.10(1 \mathrm{H}, \mathrm{m}), 4.00-4.32(3 \mathrm{H}, \mathrm{m}), 4.56(1 \mathrm{H}, \mathrm{dd}, J=$ $3.5,4.5 \mathrm{~Hz}), 5.04-5.16(1 \mathrm{H}, \mathrm{m}), 5.23-5.34(1 \mathrm{H}, \mathrm{m}), 5.80(1 \mathrm{H}, \mathrm{d}, J=3.5 \mathrm{~Hz}) . \mathrm{MS} m / z$ (relative intensity): 313 $\left(\mathrm{M}^{+}-15,6\right), 271(7), 213(30), 143$ (100). Exact $\mathrm{MS} m / z$ Calcd for $\mathrm{C}_{16} \mathrm{H}_{29} \mathrm{O}_{4} \mathrm{Si}\left(\mathrm{M}^{+}-15\right): 313.1837$. Found: 313.1835. Anal. Calcd for $\mathrm{C}_{17} \mathrm{H}_{32} \mathrm{O}_{4} \mathrm{Si}$ : C, 62.15; H, 9.82. Found: C, 62.05; H, 9.88 .

3,5-Dideoxy-1,2-O-isopropylidene-3,5-di- $C$-methyl- $\beta$-L-talofuranose (19a) and 3,5-Dideoxy-1,2-O-isopropylidene-3,5-di- $C$-methyl- $\alpha$-D-allofuranose (19b) - a) Hydrogenation of 14 with $10 \% \mathrm{Pd}-\mathrm{C}$ : An EtOAc solution $(8 \mathrm{ml})$ of $14(33 \mathrm{mg}, 0.11 \mathrm{mmol})$ was hydrogenated with $10 \% \mathrm{Pd}-\mathrm{C}(20 \mathrm{mg})$ at $0{ }^{\circ} \mathrm{C}$ for $3 \mathrm{~h}$ under ordinary hydrogen pressure. After removal of the catalyst by filtration, the filtrate was evaporated in vacuo to leave an inseparable mixture of 17a (see below) and $\mathbf{1 7 b}$, which was hydrogenated again in EtOAc $(5 \mathrm{ml})$ with $10 \% \mathrm{Pd}-\mathrm{C}(20 \mathrm{mg})$ for $10 \mathrm{~h}$ at ordinary temperature and pressure. After removal of the catalyst by filtration, evaporation of the solvent left an oil, which was subjected to silica gel thin layer chromatography (TLC) to afford two fractions. The less polar fraction gave 19a as a colorless oil $(8.7 \mathrm{mg}, 37 \%) .{ }^{1} \mathrm{H}-\mathrm{NMR}\left(\mathrm{CDCl}_{3}\right) \delta: 0.92(3 \mathrm{H}, \mathrm{d}, J=7 \mathrm{~Hz}), 1.03(3 \mathrm{H}, \mathrm{d}, J=7 \mathrm{~Hz}), 1.32(3 \mathrm{H}, \mathrm{s}), 1.51(3 \mathrm{H}$, s), $1.60-2.40(3 \mathrm{H}, \mathrm{m}), 3.69(2 \mathrm{H}, \mathrm{d}, J=6 \mathrm{~Hz}), 3.93(1 \mathrm{H}, \mathrm{dd}, J=2.5,10 \mathrm{~Hz}), 4.52(1 \mathrm{H}, \mathrm{t}, J=4 \mathrm{~Hz}), 5.75(1 \mathrm{H}, \mathrm{d}, J=$ $4 \mathrm{~Hz}$ ). MS $m / z$ (relative intensity): $201\left(\mathrm{M}^{+}-15,31\right), 157$ (29), 99 (53), 59 (100). Exact MS $m / z$ Calcd for $\mathrm{C}_{10} \mathrm{H}_{17} \mathrm{O}_{4}$ $\left(\mathrm{M}^{+}-15\right)$ : 201.1128. Found: 201.1119 .

The more polar fraction gave $19 b(6.7 \mathrm{mg}, 29 \%) .{ }^{1} \mathrm{H}-\mathrm{NMR}\left(\mathrm{CDCl}_{3}\right) \delta: 0.92(3 \mathrm{H}, \mathrm{d}, J=7 \mathrm{~Hz}), 1.05(3 \mathrm{H}, \mathrm{d}, J=$ 
$7 \mathrm{~Hz}), 1.35(3 \mathrm{H}, \mathrm{s}), 1.52(3 \mathrm{H}, \mathrm{s}), 1.60-2.40(3 \mathrm{H}, \mathrm{m}), 3.68(2 \mathrm{H}, \mathrm{d}, J=6 \mathrm{~Hz}), 3.68(1 \mathrm{H}, \mathrm{dd}, J=5,10 \mathrm{~Hz}), 4.53(1 \mathrm{H}, \mathrm{t}, J=$ $4 \mathrm{~Hz}$ ), $5.74\left(1 \mathrm{H}, \mathrm{d}, J=4 \mathrm{~Hz}\right.$ ). MS $m / z$ (relative intensity): $201\left(\mathrm{M}^{+}-15,32\right), 157$ (42), 99 (63), 71 (45), 59 (100). Exact MS $m / z$ Calcd for $\mathrm{C}_{10} \mathrm{H}_{17} \mathrm{O}_{4}\left(\mathrm{M}^{+}-15\right): 201.1127$. Found: 201.1125 .

b) Hydrogenation of 14 with $5 \% \mathrm{Rh}_{-} \mathrm{Al}_{2} \mathrm{O}_{3}: \mathrm{An} \mathrm{EtOH}$ solution $(80 \mathrm{ml})$ of $14(2.478 \mathrm{~g}, 8.15 \mathrm{mmol})$ was hydrogenated with $5 \% \mathrm{Rh}-\mathrm{Al}_{2} \mathrm{O}_{3}(1.0 \mathrm{~g})$ at $8-10{ }^{\circ} \mathrm{C}$ under ordinary pressure. After removal of the catalyst by filtration, evaporation of the solvent left an oil, which was again hydrogenated with $10 \% \mathrm{Pd}-\mathrm{C}(0.5 \mathrm{~g})$ in EtOH $(80 \mathrm{ml})$ at ordinary temperature and pressure for $6 \mathrm{~h}$. After removal of the catalyst by filtration, the filtrate was evaporated and chromatographed on a silica gel column with hexane-EtOAc $(1: 4)$ to afford 19a $(1.41 \mathrm{~g}, 80 \%)$ and 19b $(0.352 \mathrm{~g}, 20 \%)$.

c) Hydroboration of 12: A THF solution $(1 \mathrm{ml})$ of $12(0.322 \mathrm{~g}, 1.63 \mathrm{mmol})$ was added to a stirred $1 \mathrm{M}$ THF solution of $\mathrm{BH}_{3}-\mathrm{THF}$ complex $(6.5 \mathrm{ml}, 6.5 \mathrm{mmol})$ at $0{ }^{\circ} \mathrm{C}$ under argon. After $1 \mathrm{~h}$ at $0-5^{\circ} \mathrm{C}$, the solution was successively treated with $\mathrm{MeOH}(0.8 \mathrm{ml}), 3 \mathrm{~N} \mathrm{NaOH}(1 \mathrm{ml})$, and $30^{\circ} \% \mathrm{H}_{2} \mathrm{O}_{2}(1 \mathrm{ml})$ at $0^{\circ} \mathrm{C}$ and then brought to $50^{\circ} \mathrm{C}$ for $25 \mathrm{~min}$. The mixture was extracted with ether, and the extract was washed with $2 \mathrm{~N} \mathrm{HCl}$ and brine, $\operatorname{dried}\left(\mathrm{MgSO}_{4}\right)$, and evaporated in vacuo. The residue was chromatographed on a silica gel column with $\mathrm{Et}_{2} \mathrm{O}$-hexane $(4: 1)$ to afford a mixture of $19 \mathrm{a}$ and $19 \mathrm{~b}(0.207 \mathrm{~g}, 59 \%)$. The ratio of $19 \mathrm{a}$ and $19 \mathrm{~b}$ was determined to be $1: 6.8$ from the C-4 proton signals (3.93 ppm for 19a and $3.68 \mathrm{ppm}$ for 19b) in the NMR spectrum.

d) Hydroboration of 14: A THF solution of $1 \mathrm{M} \mathrm{BH}_{3}-\mathrm{THF}(4 \mathrm{ml}, 4 \mathrm{mmol})$ was added to a solution of $14(1.2 \mathrm{~g}$, $3.95 \mathrm{mmol})$ in THF $(20 \mathrm{ml})$ at $-20^{\circ} \mathrm{C}$, and the solution was stirred for $9 \mathrm{~h}$ at $-10^{\circ} \mathrm{C}$. The excess $\mathrm{BH}_{3}$ was decomposed with $\mathrm{MeOH}(2 \mathrm{ml})$ at $-10 \mathrm{C}$, and $4 \mathrm{~N} \mathrm{NaOH}(1.65 \mathrm{ml})$ and $70 \%$ tert $-\mathrm{BuOOH}(0.6 \mathrm{ml})$ were added to the resulting mixture at $-10 \mathrm{C}$. The mixture was stirred for $0.5 \mathrm{~h}$ at $-10^{\circ} \mathrm{C}$, then evaporated in vacuo, and extracted with $\mathrm{CH}_{2} \mathrm{Cl}_{2}$. The extract was washed with brine, dried $\left(\mathrm{MgSO}_{4}\right)$, and evaporated to leave an oil, which was chromatographed on a silica gel column with hexane-EtOAc $(2: 1)$ to give a mixture of 20a and $20 \mathrm{~b}(1.03 \mathrm{~g}, 82 \%)$. The ratio of 20a and $20 \mathbf{b}$ was determined to be $24: 1$ from the anomeric proton signals ( 5.75 for 20a and 5.71 for 20b) in the NMR spectrum. ${ }^{1} \mathrm{H}-\mathrm{NMR}\left(\mathrm{CDCl}_{3}\right) \delta: 1.05(3 \mathrm{H}, \mathrm{d}, J=6.5 \mathrm{~Hz}), 1.32(3 \mathrm{H}, \mathrm{s}), 1.49(3 \mathrm{H}, \mathrm{s}), 1.90-2.10(2 \mathrm{H}, \mathrm{m})$, $2.68(1 \mathrm{H}, \mathrm{dd}, J=3,8.5 \mathrm{~Hz}), 3.67(1 \mathrm{H}, \mathrm{dd}, J=6,9 \mathrm{~Hz}), 3.70-3.88(3 \mathrm{H}, \mathrm{m}), 3.92(1 \mathrm{H}, \mathrm{dd}, J=3,11 \mathrm{~Hz}), 4.54(1 \mathrm{H}, \mathrm{dd}$, $J=3.5,4.5 \mathrm{~Hz}), 4.55(2 \mathrm{H}, \mathrm{s}), 3.75(1 \mathrm{H}, \mathrm{d}, J=3.5 \mathrm{~Hz}), 7.33(5 \mathrm{H}, \mathrm{s})$.

The mixture $(20 \mathrm{mg}, 0.06 \mathrm{mmol})$ was treated with methanesulfonyl chloride $(\mathrm{MsCl})(14 \mathrm{mg}, 0.12 \mathrm{mmol})$ in $\mathrm{CH}_{2} \mathrm{Cl}_{2}(0.2 \mathrm{ml})$ and pyridine $(0.1 \mathrm{ml})$ at room temperature. After $1.5 \mathrm{~h}$, the solution was diluted with $\mathrm{CH}_{2} \mathrm{Cl}_{2}$, washed with cold $2 \mathrm{~N} \mathrm{HCl}$ and brine, dried $\left(\mathrm{MgSO}_{4}\right)$, and evaporated in vacuo. The residue was chromatographed on a silica gel column with hexane-EtOAc $(3: 2)$ to give a mixture of mesylates $(19 \mathrm{mg}, 76.5 \%)$, which $(17.6 \mathrm{mg}, 0.044 \mathrm{mmol})$ in $\mathrm{Et}_{2} \mathrm{O}(0.5 \mathrm{ml})$ was reduced with $\mathrm{LAH}(45 \mathrm{mg}, 1.18 \mathrm{mmol})$ at $0{ }^{\circ} \mathrm{C}$ for $6.5 \mathrm{~h}$ to give a mixture of $17 \mathbf{a}$ and $17 \mathbf{b}(9.6 \mathrm{mg}$, $71 \%)$. The mixture $(9.6 \mathrm{mg}, 0.031 \mathrm{mmol})$ was hydrogenated with $10 \% \mathrm{Pd}-\mathrm{C}(5 \mathrm{mg})$ in EtOH $(0.2 \mathrm{ml})$ at room temperature for $6 \mathrm{~h}$. After removal of the catalyst by filtration, the filtrate was concentrated in vacuo, dissolved in $\mathrm{Et}_{2} \mathrm{O}$, and passed through a silica gel column to give a mixture of 19a and 19b $(6.8 \mathrm{mg}, 100 \%)$. The ratio of 19a and 19b was determined to be $24: 1$ from the NMR spectrum.

e) Reduction of $21 \mathrm{a}$ : A solution of $21 \mathrm{a}(44.7 \mathrm{~g}, 0.129 \mathrm{~mol})$ and $\mathrm{TsCl}(36.9 \mathrm{~g}, 0.193 \mathrm{~mol})$ in pyridine $(220 \mathrm{ml})$ was allowed to stand overnight at room temperature, then poured into ice-water, and extracted with $\mathrm{CH}_{2} \mathrm{Cl}_{2}$. The extract was washed with ice-cold $1 \mathrm{~N} \mathrm{HCl}$, saturated $\mathrm{NaHCO}_{3}$ and brine, dried $\left(\mathrm{MgSO}_{4}\right)$, and evaporated to give tosylate $(61.6 \mathrm{~g}, 95 \%) \cdot[\alpha]_{\mathrm{D}}^{20}+13.3^{\circ}(c=1.26, \mathrm{MeOH}) \cdot{ }^{1} \mathrm{H}-\mathrm{NMR}\left(\mathrm{CDCl}_{3}\right) \delta: 0.07(6 \mathrm{H}, \mathrm{s}), 0.81(9 \mathrm{H}, \mathrm{s}), 1.06(3 \mathrm{H}, \mathrm{d}, J=7.0 \mathrm{~Hz})$, $1.30(3 \mathrm{H}, \mathrm{s}), 1.46(3 \mathrm{H}, \mathrm{s}), 1.91-2.06(2 \mathrm{H}, \mathrm{m}), 2.44(3 \mathrm{H}, \mathrm{s}), 3.57(2 \mathrm{H}, \mathrm{d}, J=6.5 \mathrm{~Hz}), 3.81(1 \mathrm{H}, \mathrm{dd}, J=3.0,10.5 \mathrm{~Hz})$, $3.99(1 \mathrm{H}, \mathrm{dd}, J=6.0,10.0 \mathrm{~Hz}), 4.48(1 \mathrm{H}, \mathrm{t}, J=4.0 \mathrm{~Hz}), 5.65(1 \mathrm{H}, \mathrm{d}, J=4.0 \mathrm{~Hz}), 7.34(2 \mathrm{H}, \mathrm{d}, J=8.0 \mathrm{~Hz}), 7.78(2 \mathrm{H}, \mathrm{d}$, $J=8.0 \mathrm{~Hz}$ ). MS $m / z$ (relative intensity): $485\left(\mathrm{M}^{+}-15,9.9\right), 443(8), 385(5.5), 229(100)$. Exact MS $m / z$ Calcd for $\mathrm{C}_{23} \mathrm{H}_{37} \mathrm{O}_{7} \mathrm{SSi}\left(\mathrm{M}^{+}-15\right): 485.2046$. Found: 485.2031 .

The tosylate $(51.3 \mathrm{~g}, 0.102 \mathrm{~mol})$ in ether $(250 \mathrm{ml})$ was added to a stirred ice-cold suspension of LAH $(23.3 \mathrm{~g}$, $0.616 \mathrm{~mol})$ in ether $(230 \mathrm{ml})$. After $5 \mathrm{~h}$ at room temperature, EtOAc, then water $(23 \mathrm{ml})$, and $15 \% \mathrm{NaOH}(23 \mathrm{ml})$ were added carefully. The resulting mixture was filtered through celite and the solid was washed with ether. The combined ether layers were dried $\left(\mathrm{MgSO}_{4}\right)$ and evaporated in vacuo to give an oil, which was chromatographed on a silica gel column with EtOAc-hexane $(1: 2)$ as the eluant to give $19 \mathrm{a}$ as an oil $(21.0 \mathrm{~g}, 95 \%)$.

5-C-(tert-Butyldimethylsilyloxy)methyl-1,3-dideoxy-1,2-O-isopropylidene-3- $C$-methyl- $\beta$-L-talofuranose (21a) and 5-C-(tert-Butyldimethylsilyloxy)methyl-3,5-dideoxy-1,2, $O$-isopropylidene-3- $C$-methyl- $\alpha$-D-allofuranose (21b) - A $1 \mathrm{~m}$ THF solution of $\mathrm{BH}_{3}$-THF complex $(6.55 \mathrm{ml}, 6.6 \mathrm{mmol})$ was added to a stirred solution of $16(2.15 \mathrm{~g}$, $6.6 \mathrm{mmol})$ in THF $(7 \mathrm{ml})$ at $0{ }^{\circ} \mathrm{C}$ under argon. After $1 \mathrm{~h}$ at $0{ }^{\circ} \mathrm{C}$, the solution was cooled to $-16^{\circ} \mathrm{C}$, and treated with $4.15 \mathrm{~N} \mathrm{NaOH}(2.6 \mathrm{ml})$ and $70 \%$ aqueous tert $-\mathrm{BuOOH}$ solution $(1.0 \mathrm{ml})$. After $3 \mathrm{~h}$, the reaction mixture was diluted with ether, washed with brine, dried $\left(\mathrm{MgSO}_{4}\right)$, and evaporated in vacuo to leave an oil, which was chromatographed on a silica gel column with EtOAc-hexane $(1: 16-1: 5)$ to afford $21 \mathrm{~b}$ as a colorless oil $(0.17 \mathrm{~g}, 7.5 \%)$ from the first fraction. $[\alpha]_{\mathrm{D}}^{20}+30^{\circ}(c=1.38, \mathrm{MeOH}) .{ }^{1} \mathrm{H}-\mathrm{NMR}\left(\mathrm{CDCl}_{3}\right) \delta: 0.07(3 \mathrm{H}, \mathrm{s}), 0.08(3 \mathrm{H}, \mathrm{s}), 0.90(9 \mathrm{H}, \mathrm{s}), 1.10(3 \mathrm{H}, \mathrm{d}, J=$ $7.0 \mathrm{~Hz}), 1.32(3 \mathrm{H}, \mathrm{s}), 1.50(3 \mathrm{H}, \mathrm{s}), 1.82-2.13(2 \mathrm{H}, \mathrm{m}), 2.76(1 \mathrm{H}, \mathrm{t}, J=6.0 \mathrm{~Hz}), 3.74-4.17(5 \mathrm{H}, \mathrm{m}), 4.52(1 \mathrm{H}, \mathrm{dd}, J=$ $3.5,4.5 \mathrm{~Hz}), 5.74(1 \mathrm{H}, \mathrm{d}, J=3.5 \mathrm{~Hz})$. MS $m / z$ (relative intensity): $331\left(\mathrm{M}^{+}-15,9.9\right), 285(5.5), 229$ (100). Exact MS $m / z$ Calcd for $\mathrm{C}_{16} \mathrm{H}_{31} \mathrm{O}_{5} \mathrm{Si}\left(\mathrm{M}^{+}-15\right)$ : 331.1943. Found: 331.1933 .

The second fraction gave $21 \mathrm{a}$ as a colorless oil $(1.9 \mathrm{~g}, 84 \%)$. IR $v_{\max }^{\text {neat }} \mathrm{cm}^{-1}: 3400 .[\alpha]_{\mathrm{D}}^{20}+41^{\circ}(c=1.28, \mathrm{MeOH})$. 
${ }^{1} \mathrm{H}-\mathrm{NMR}\left(\mathrm{CDCl}_{3}\right) \delta: 0.08(6 \mathrm{H}, \mathrm{s}), 0.90(9 \mathrm{H}, \mathrm{s}), 1.06(3 \mathrm{H}, \mathrm{d}, J=7.0 \mathrm{~Hz}), 1.33(3 \mathrm{H}, \mathrm{s}), 1.50(3 \mathrm{H}, \mathrm{s}), 1.79-2.17(2 \mathrm{H}, \mathrm{m})$, $2.79(1 \mathrm{H}, \mathrm{dd}, J=3.0,8.5 \mathrm{~Hz}), 3.69-3.96(5 \mathrm{H}, \mathrm{m}), 4.55(1 \mathrm{H}, \mathrm{t}, J=4.0 \mathrm{~Hz}), 5.76(1 \mathrm{H}, \mathrm{d}, J=4.0 \mathrm{~Hz})$. MS $m / z$ (relative intensity): $331\left(\mathrm{M}^{+}-15,6.4\right), 231$ (12.3), $213(8), 201$ (12), 75 (100). Exact MS $m / z$ Calcd for $\mathrm{C}_{16} \mathrm{H}_{31} \mathrm{O}_{5} \mathrm{Si}\left(\mathrm{M}^{+}-15\right)$ : 331.1943. Found: 331.1962 .

6-O-Benzyl-3,5-dideoxy-1,2- $O$-isopropylidene-3,5-di- $C$-methyl- $\beta$-L-talofuranose (17a) - A solution of 19 $(1.50 \mathrm{~g}, 7.13 \mathrm{mmol})$ in THF $(8 \mathrm{ml})$ was added portionwise to a stirred suspension of $\mathrm{NaH}(0.24 \mathrm{~g}, 9.99 \mathrm{mmol})$ in DMSO $(6 \mathrm{ml})$ was added portionwise at room temperature. After gas evolution had ceased, benzyl chloride $(0.948 \mathrm{~g}$, $7.49 \mathrm{mmol}$ ) was added. The reaction mixture was stirred for $20 \mathrm{~h}$, poured into cold aqueous $\mathrm{NH}_{4} \mathrm{Cl}$, and extracted with ether. The extract was washed with water and brine, dried $\left(\mathrm{MgSO}_{4}\right)$, and evaporated in vacuo to leave an oil, which was chromatographed on a silica gel column with hexane-EtOAc $(4: 1)$ to give $17 \mathbf{a}$ as a colorless oil $(2.00 \mathrm{~g}$. $89 \%) \cdot[\alpha]_{\mathrm{D}}^{19}+19^{\circ}\left(c=1.90, \mathrm{CHCl}_{3}\right) \cdot{ }^{1} \mathrm{H}-\mathrm{NMR}\left(\mathrm{CDCl}_{3}\right) \delta: 0.91(3 \mathrm{H}, \mathrm{d}, J=7.0 \mathrm{~Hz}), 1.02(3 \mathrm{H}, \mathrm{d}, J=7.0 \mathrm{~Hz}), 1.33(3 \mathrm{H}$, s), $1.51(3 \mathrm{H}, \mathrm{s}), 1.77-2.08(2 \mathrm{H}, \mathrm{m}), 3.41(1 \mathrm{H}, \mathrm{dd}, J=8.0,14 \mathrm{~Hz}), 3.55(1 \mathrm{H}, \mathrm{dd}, J=8.0,14 \mathrm{~Hz}), 3.91(1 \mathrm{H}, \mathrm{dd}, J=2.5$, $10.5 \mathrm{~Hz}), 4.52(1 \mathrm{H}, \mathrm{dd}, J=3.5,4.5 \mathrm{~Hz}), 4.53(2 \mathrm{H}, \mathrm{s}), 5.74(1 \mathrm{H}, \mathrm{d}, J=3.5 \mathrm{~Hz}), 7.32(5 \mathrm{H}, \mathrm{s}) . \mathrm{MS} m / z$ (relative intensity): $306\left(\mathrm{M}^{+}, 2.3\right), 291$ (4.3), 248 (2.3), 231 (2.6), 157 (9.0), 91 (100). Exact MS $m / z$ Calcd for $\mathrm{C}_{18} \mathrm{H}_{26} \mathrm{O}_{4}\left(\mathrm{M}^{+}\right): 306.1833$. Found: 306.1829.

6- $O$-Benzyl-3,5-dideoxy-3,5-di- $C$-methyl-L-talofuranose (28) - A solution of 17 a $(20.0 \mathrm{~g}, 65.4 \mathrm{mmol})$ in THF $(750 \mathrm{ml})$ and $4 \mathrm{~N} \mathrm{HCl}(250 \mathrm{ml})$ was allowed to stand for $10.5 \mathrm{~h}$ at $40 \mathrm{C}$, then neutralized with $\mathrm{NaHCO}_{3}$, and evaporated in vacuo. The residue was extracted with $\mathrm{CH}_{2} \mathrm{Cl}_{2}$, dried $\left(\mathrm{MgSO}_{4}\right)$, and evaporated in vacuo to leave an oil, which was chromatographed on a silica gel column with EtOAc-hexane (1:1) to afford 28 as a colorless oil (14.5 g, $83 \%$ ). MS $m / z$ (relative intensity): $248\left(\mathrm{M}^{+}-18,5.3\right), 107(28), 91$ (100). Exact $\mathrm{MS} m / z$ Calcd for $\mathrm{C}_{15} \mathrm{H}_{20} \mathrm{O}_{3}$ $\left(\mathrm{M}^{+}-18\right): 248.1412$. Found: 248.1432 .

5- $\boldsymbol{O}$-Benzyl-2,4-dideoxy-3- $\boldsymbol{O}$-formyl-2,4-di- $\boldsymbol{C}$-methyl-L-lyxose (29)—A solution of $\mathrm{NaIO}_{4}(8.75 \mathrm{~g}, 40.9 \mathrm{mmol})$ in water $(60 \mathrm{ml})$ was added to a stirred solution of $28(7.25 \mathrm{~g}, 27.3 \mathrm{mmol})$ in $\mathrm{MeOH}(110 \mathrm{ml})$ at $0 \mathrm{C}$. After $1 \mathrm{~h}$, the reaction mixture was filtered and the filtrate was evaporated in vacuo. The residue was extracted with $\mathrm{CH}_{2} \mathrm{Cl}_{2}$, then the extract was dried $\left(\mathrm{MgSO}_{4}\right)$, and evaporated in vacuo to give 29 as an oil $(6.8 \mathrm{~g}, 94.4 \%)$. IR $v_{\max }^{\text {neal }} \mathrm{cm}^{-1}: 1720 .{ }^{1} \mathrm{H}$ NMR $\left(\mathrm{CDCl}_{3}\right) \delta: 0.96(3 \mathrm{H}, \mathrm{d}, J=7.0 \mathrm{~Hz}), 1.13(3 \mathrm{H}, \mathrm{d}, J=7.5 \mathrm{~Hz}), 1.98-2.30(1 \mathrm{H}, \mathrm{m}), 2.75(1 \mathrm{H}, \mathrm{ddq}, J=2.5,7.0$, $7.5 \mathrm{~Hz}), 3.20(1 \mathrm{H}, \mathrm{dd}, J=2,16 \mathrm{~Hz}), 3.40(1 \mathrm{H}, \mathrm{d}, J=16 \mathrm{~Hz}), 4.45(2 \mathrm{H}, \mathrm{s}), 5.42(1 \mathrm{H}, \mathrm{dd}, J=7.0,7.5 \mathrm{~Hz}), 7.32(5 \mathrm{H}, \mathrm{s})$, $8.01(1 \mathrm{H}, \mathrm{s}), 9.63(1 \mathrm{H}, \mathrm{d}, J=2.5 \mathrm{~Hz}) . \mathrm{MS} m / z$ (relative intensity): $264\left(\mathrm{M}^{+}, 0.3\right), 188(2.4), 160(5.1), 145(3.3), 112$ (12), 107 (8), 91 (100). Exact MS $m / z$ Calcd for $\mathrm{C}_{15} \mathrm{H}_{20} \mathrm{O}_{4}\left(\mathrm{M}^{+}\right): 264.1361$. Found: 264.1367.

$(2 Z, 4 S, 5 S, 6 S)$-7-O-Benzyloxy-5-hydroxy-2,4,6-trimethylhept-2-enoic Acid $\delta$-Lactone (30)- $(\mathrm{MeO})_{2} \mathrm{P}(\mathrm{O}) \mathrm{CH}$ $(\mathrm{Me}) \mathrm{CO}_{2} \mathrm{Me}(2.7 \mathrm{~g}, 13.8 \mathrm{mmol})$ was added to a stirred suspension of $\mathrm{NaH}(270 \mathrm{mg}, 11.2 \mathrm{mmol})$ in $\mathrm{THF}(50 \mathrm{ml})$ at $0^{\circ} \mathrm{C}$. After $1 \mathrm{~h}$, the solution was cooled at $-80^{\circ} \mathrm{C}$ and then $29(1.21 \mathrm{~g}, 4.58 \mathrm{mmol})$ in THF $(20 \mathrm{ml})$ was added dropwise at below $-80^{\circ} \mathrm{C}$. The solution was allowed to warm to $8^{\circ} \mathrm{C}$ overnight, treated with saturated $\mathrm{NH}_{4} \mathrm{Cl}$, and extracted with ether. The extract was washed with water and brine, dried $\left(\mathrm{Na}_{2} \mathrm{SO}_{4}\right)$, and evaporated in vacuo to leave an oil, which was dissolved in $\mathrm{MeOH}(30 \mathrm{ml})$ and treated with $\mathrm{K}_{2} \mathrm{CO}_{3}(0.5 \mathrm{~g})$ at room temperature for $1 \mathrm{~h}$. The reaction mixture was neutralized with $\mathrm{NH}_{4} \mathrm{Cl}(0.5 \mathrm{~g})$ ad evaporated in vacuo. The residue was extracted with benzene, then the extract was dried $\left(\mathrm{Na}_{2} \mathrm{SO}_{4}\right)$, and evaporated to leave an oil, which was chromatographed on a silica gel column with hexaneEtOAc $(8: 1)$ to give 30 as a colorless oil $(1.15 \mathrm{~g}, 92 \%) .{ }^{1} \mathrm{H}-\mathrm{NMR}\left(\mathrm{CDCl}_{3}\right) \delta: 0.98(3 \mathrm{H}, \mathrm{d}, J=8 \mathrm{~Hz}), 1.08(3 \mathrm{H}, \mathrm{d}, J=$ $8 \mathrm{~Hz}), 1.90(3 \mathrm{H}, \mathrm{dd}, J=1.5,2 \mathrm{~Hz}), 1.95-2.36(1 \mathrm{H}, \mathrm{m}), 1.36-2.88(1 \mathrm{H}, \mathrm{m}), 3.48(1 \mathrm{H}, \mathrm{dd}, J=6,10 \mathrm{~Hz}), 3.63(1 \mathrm{H}, \mathrm{t}$, $J=10 \mathrm{~Hz}), 4.27(1 \mathrm{H}, \mathrm{dd}, J=3,12 \mathrm{~Hz}), 4.52(2 \mathrm{H}, \mathrm{s}), 6.32(1 \mathrm{H}, \mathrm{dq}, J=4,2 \mathrm{~Hz}), 7.10(5 \mathrm{H}, \mathrm{s}) . \mathrm{MS} m / z$ (relative intensity): $274\left(\mathrm{M}^{+}, 6.7\right), 214(7.5), 161$ (37), 125 (38), 91 (100). Exact MS $m / z$ Calcd for $\mathrm{C}_{17} \mathrm{H}_{22} \mathrm{O}_{3}\left(\mathrm{M}^{+}\right): 274.1570$. Found: 274.1584 .

(2S,5S,6S)-2H-5,6-Dihydro-2-isopropyloxy-3,5-dimethyl-6-[1(S)-methyl-2-benzyloxyethyl]pyran (31)-A $1 \mathrm{M}$ toluene solution of DIBAH $(49.3 \mathrm{ml}, 49.3 \mathrm{mmol})$ was added to a stirred solution of $\mathbf{3 0}(9.0 \mathrm{~g}, 32.8 \mathrm{mmol}) \mathrm{in}$ toluene $(360 \mathrm{ml})$ at $-80^{\circ} \mathrm{C}$. The solution was then treated with $\mathrm{MeOH}(50 \mathrm{ml})$. After $40 \mathrm{~min}$, the reaction mixture was allowed to warm to room temperature, and treated with brine $(250 \mathrm{ml})$ and $1 \mathrm{~N} \mathrm{HCl}(60 \mathrm{ml})$. The resulting mixture was extracted with ether, then the extract was washed with $\mathrm{NaHCO}_{3}$ and brine, dried $\left(\mathrm{MgSO}_{4}\right)$, and evaporated in vacuo to afford the crude lactol $(9.0 \mathrm{~g}, 99.4 \%)$ as an oil. The lactol $(9.0 \mathrm{~g}, 32.6 \mathrm{mmol})$ was treated with camphorsulfonic acid (CSA) $(0.5 \mathrm{~g}, 2.15 \mathrm{mmol})$ in $\mathrm{Me}_{2} \mathrm{CHOH}(90 \mathrm{ml})$ in $1 \mathrm{~h}$ at room temperature. After addition of $\mathrm{NEt}_{3}(10 \mathrm{ml})$, the mixture was stirred for $10 \mathrm{~min}$, concentrated in vacuo, and extracted with ether. The extract was washed with $1 \mathrm{~N} \mathrm{HCl}$, saturated $\mathrm{NaHCO}_{3}$ and brine, dried $\left(\mathrm{MgSO}_{4}\right)$, and evaporated in vacuo to leave an oil, which was chromatographed on a silica gel column with EtOAc-hexane $(1: 10)$ to afford 31 as a colorless oil $(10.0 \mathrm{~g}, 97 \%) .{ }^{1} \mathrm{H}-\mathrm{NMR}\left(\mathrm{CDCl}_{3}\right) \delta$ : $0.88(3 \mathrm{H}, \mathrm{d}, J=7 \mathrm{~Hz}), 0.93(3 \mathrm{H}, \mathrm{d}, J=7 \mathrm{~Hz}), 1.16(3 \mathrm{H}, \mathrm{d}, J=6 \mathrm{~Hz}), 1.17(3 \mathrm{H}, \mathrm{d}, J=6 \mathrm{~Hz}), 1.68(3 \mathrm{H}, \mathrm{t}, J=2.0 \mathrm{~Hz})$, $1.90-2.50(2 \mathrm{H}, \mathrm{m}), 3.45(1 \mathrm{H}, \mathrm{dd}, J=8,16 \mathrm{~Hz}), 3.53(1 \mathrm{H}, \mathrm{dd}, J=8,16 \mathrm{~Hz}), 3.64(1 \mathrm{H}, \mathrm{dd}, J=2,12 \mathrm{~Hz}), 3.96(1 \mathrm{H}$, sept, $J=6 \mathrm{~Hz}), 4.45(1 \mathrm{H}, \mathrm{d}, J=12 \mathrm{~Hz}), 4.57(1 \mathrm{H}, \mathrm{d}, J=12 \mathrm{~Hz}), 4.79(1 \mathrm{H}, \mathrm{br} \mathrm{s}), 5.43(1 \mathrm{H}, \mathrm{br} \mathrm{s}), 7.31(5 \mathrm{H}, \mathrm{s})$. MS $m / z$ (relative intensity): $318\left(\mathrm{M}^{+}, 1.3\right), 259(6), 167(10), 140(50), 98(100)$. Exact $\mathrm{MS} m / z$ Calcd for $\mathrm{C}_{20} \mathrm{H}_{30} \mathrm{O}_{3}\left(\mathrm{M}^{+}\right): 318.2196$. Found: 318.2181 .

$(2 S, 3 R, 5 S, 6 S)$-2-Isopropyloxy-3,5-dimethyl-6-[1(S)-methyl-2-hydroxyethyl]tetrahydropyran (7a) and $(2 S, 3 S$,$5 S, 6 S)$-2-Isopropyloxy-3,5-dimethyl-6-[1(S)-methyl-2-hydroxyethyl]tetrahydropyran (7b)-a) Hydrogenation of 31: A solution of $31(2.7 \mathrm{~g}, 8.49 \mathrm{mmol})$ in EtOAc $(30 \mathrm{ml})$ was hydrogenated over $10 \% \mathrm{Pd}-\mathrm{C}(0.9 \mathrm{~g})$ at ordinary 
temperature and pressure for $21 \mathrm{~h}$. The catalyst was removed by filtration, and the filtrate was concentrated in vacuo to leave 32 as an oil. MS $m / z$ (relative intensity): $320\left(\mathrm{M}^{+}, 0.3\right), 278(0.5), 260$ (1.7), 91 (100). Exact MS $m / z$ Calcd for $\mathrm{C}_{17} \mathrm{H}_{24} \mathrm{O}_{2}\left(\mathrm{M}^{+}-60\right): 260.1776$. Found: 260.1767 .

Compound 32 was dissolved in EtOH $(15 \mathrm{ml})$ and hydrogenated again over Raney Ni W-2 (10 ml of precipitate in $\mathrm{EtOH}$ ) for $24 \mathrm{~h}$. After removal of the catalyst, the filtrate was concentrated in vacuo to leave an oil, which was chromatographed on a silica gel column with EtOAc-benzene $(1: 20)$ to afford $7 \mathrm{a}$ as a colorless oil $(1.7 \mathrm{~g}, 87 \%)$ from the first fraction. ${ }^{1} \mathrm{H}-\mathrm{NMR}\left(\mathrm{CDCl}_{3}\right) \delta: 0.80(3 \mathrm{H}, \mathrm{d}, J=7 \mathrm{~Hz}), 0.83(3 \mathrm{H}, \mathrm{d}, J=7 \mathrm{~Hz}), 1.00(3 \mathrm{H}, \mathrm{d}, J=7 \mathrm{~Hz}), 1.10(3 \mathrm{H}$, $\mathrm{d}, J=6 \mathrm{~Hz}), 1.24(3 \mathrm{H}, \mathrm{d}, J=6 \mathrm{~Hz}), 1.50-2.04(3 \mathrm{H}, \mathrm{m}), 2.76(1 \mathrm{H}, \mathrm{dd}, J=3.5,8 \mathrm{~Hz}), 3.50-3.84(3 \mathrm{H}, \mathrm{m}), 3.77(1 \mathrm{H}$, sept. $J=6 \mathrm{~Hz}), 4.65(1 \mathrm{H}, \mathrm{d}, J=4 \mathrm{~Hz})$. MS $m / z$ (relative intensity): $171\left(\mathrm{M}^{+}-59,43\right), 143(26), 139(19), 100(19), 89$ (40), 81 (36), 72 (74), 71 (82), 43 (100). Exact MS $m / z$ Calcd for $\mathrm{C}_{10} \mathrm{H}_{19} \mathrm{O}_{2}\left(\mathrm{M}^{+}-59\right)$ : 171.1385. Found: 171.1379.

The second fraction gave $7 \mathrm{~b}(0.234 \mathrm{~g}, 12 \%) .{ }^{1} \mathrm{H}-\mathrm{NMR}\left(\mathrm{CDCl}_{3}\right) \delta: 0.77(3 \mathrm{H}, \mathrm{d}, J=6 \mathrm{~Hz}), 1.03(3 \mathrm{H}, \mathrm{d}, J=7 \mathrm{~Hz})$, $1.12(3 \mathrm{H}, \mathrm{d}, J=6 \mathrm{~Hz}), 1.23(3 \mathrm{H}, \mathrm{d}, J=6 \mathrm{~Hz}), 1.40-2.10(3 \mathrm{H}, \mathrm{m}), 3.50-3.90(3 \mathrm{H}, \mathrm{m}), 3.88(1 \mathrm{H}, \mathrm{sept}, J=6 \mathrm{~Hz}), 4.57$ $(1 \mathrm{H}, \mathrm{s})$. MS $m / z$ (relative intensity): $230\left(\mathrm{M}^{+}, 0.2\right), 188(10), 171$ (15), $119(22), 100(88), 89(55), 82(53), 69$ (63), 58 (100). Exact $\mathrm{MS} m / z$ Calcd for $\mathrm{C}_{13} \mathrm{H}_{26} \mathrm{O}_{3}\left(\mathrm{M}^{+}\right)$: 230.1882. Found: 230.1881 .

b) Hydrogenation of $\mathbf{3 8}$ with $\mathrm{Pd}-\mathrm{C}$ : A solution of $\mathbf{3 8}(6 \mathrm{mg}, 0.0263 \mathrm{mmol})$ in EtOAc $(1 \mathrm{ml})$ at $0^{\circ} \mathrm{C}$ was hydrogenated with $10 \% \mathrm{Pd}-\mathrm{C}(5 \mathrm{mg})$ for $9 \mathrm{~h}$. After removal of the catalyst, evaporation of the solvent left an oil, which was chromatographed on a silica gel column with hexane-benzene $(1: 1)$ to give a mixture of $7 \mathbf{a}$ and $7 \mathbf{b}$ as a colorless oil $(2.8 \mathrm{mg}, 46 \%)$. The ratio of $7 \mathbf{a}$ and $7 \mathbf{b}$ was determined to be $5: 1$ from the anomeric proton signals (4.66 ppm for $7 \mathbf{a}$ and $4.47 \mathrm{ppm}$ for $7 \mathbf{b}$ ) in the NMR spectrum.

c) Hydrogenation of 38 with $\mathrm{Rh}-\mathrm{Al}_{2} \mathrm{O}_{3}$ : A solution of $38(17 \mathrm{mg}, 0.0745 \mathrm{mmol})$ in ether $(3.5 \mathrm{ml})$ was hydrogenated with $\mathrm{Rh}-\mathrm{Al}_{2} \mathrm{O}_{3}(20 \mathrm{mg})$ at room temperature overnight. After removal of the catalyst, the filtrate was evaporated to leave an oil, which was dissolved in EtOAc and passed through a silica gel column to give a 24:1 mixture of $7 \mathbf{a}$ and $7 \mathbf{b}(7.1 \mathrm{mg}, 99 \%)$.

3,5-Dideoxy-1,2- $O$-isopropylidene-6-(4-methoxybenzyl)-3,5-dimethyl- $\boldsymbol{\beta}$-L-talofuranose (33)_Compound 19a $(2.908 \mathrm{~g}, 13.46 \mathrm{mmol})$ was treated with $\mathrm{NaH}(0.387 \mathrm{~g}, 16.13 \mathrm{mmol})$ and 4-methoxybenzyl chloride (MPMC1) $(2.53 \mathrm{~g}$, $16.17 \mathrm{mmol})$ in DMSO $(18 \mathrm{ml})$ as described for the preparation of $17 \mathbf{a}$ to give 33 as a colorless oil $(1.266 \mathrm{~g}, 99 \%) .{ }^{1} \mathrm{H}$ $\operatorname{NMR}\left(\mathrm{CDCl}_{3}\right) \delta: 0.89(3 \mathrm{H}, \mathrm{d}, J=7 \mathrm{~Hz}), 1.02(3 \mathrm{H}, \mathrm{d}, J=7 \mathrm{~Hz}), 1.33(3 \mathrm{H}, \mathrm{s}), 1.50(3 \mathrm{H}, \mathrm{s}), 1.80-2.05(2 \mathrm{H}, \mathrm{m}), 3.39$ $(1 \mathrm{H}, \mathrm{dd}, J=7.5,9 \mathrm{~Hz}), 3.50(1 \mathrm{H}, \mathrm{dd}, J=6.5,9 \mathrm{~Hz}), 3.80(3 \mathrm{H}, \mathrm{s}), 3.88(1 \mathrm{H}, \mathrm{dd}, J=2,10 \mathrm{~Hz}), 4.43(1 \mathrm{H}, \mathrm{d}, J=11.5 \mathrm{~Hz})$, $4.48(1 \mathrm{H}, \mathrm{d}, J=11.5 \mathrm{~Hz}), 4.52(1 \mathrm{H}, \mathrm{dd}, J=3.5,5 \mathrm{~Hz}), 5.74(1 \mathrm{H}, \mathrm{d}, J=3.5 \mathrm{~Hz}), 6.86(2 \mathrm{H}, \mathrm{d}, J=9 \mathrm{~Hz}), 7.26(2 \mathrm{H}, \mathrm{d}, J=$ $9 \mathrm{~Hz}$ ). MS $m / z$ (relative intensity): $336\left(\mathrm{M}^{+}, 2.6\right), 278(1.3), 260(1.0), 232$ (1.5), $215(1.1), 207(3.0), 190(4.0), 277$ (2.8), 157 (8.0), 137 (52), 121 (100). Exact MS $m / z$ Calcd for $\mathrm{C}_{19} \mathrm{H}_{28} \mathrm{O}_{5}\left(\mathrm{M}^{+}\right)$: 336.1936. Found: 336.1936.

6-O-(4-Methoxybenzyl)-3,5-dideoxy-3,5-di- $\boldsymbol{C}$-methyl-L-talofuranose (34)-Compound 33 (4.50 g, 13.45 mmol) was hydrolyzed with $4 \mathrm{~N} \mathrm{HCl}(30 \mathrm{ml})$ in dioxane $(73 \mathrm{ml})$ at $45^{\circ} \mathrm{C}$ for $100 \mathrm{~min}$ as described for the preparation of 28 to give 34 as a colorless oil $(3.10 \mathrm{~g}, 78 \%) .{ }^{1} \mathrm{H}-\mathrm{NMR}\left(\mathrm{CDCl}_{3}\right) \delta: 0.90(0.9 \mathrm{H}, \mathrm{d}, J=7 \mathrm{~Hz}), 0.96(2.1 \mathrm{H}, \mathrm{d}, J=7 \mathrm{~Hz})$, $1.04(3 \mathrm{H}, \mathrm{d}, J=9 \mathrm{~Hz}), 1.70-2.50(3 \mathrm{H}, \mathrm{m}), 2.64(0.3 \mathrm{H}, \mathrm{d}, J=7.5 \mathrm{~Hz}), 3.16(0.7 \mathrm{H}, \mathrm{d}, J=3.5 \mathrm{~Hz}), 3.20-3.70(2 \mathrm{H}, \mathrm{m})$, $3.80(3 \mathrm{H}, \mathrm{s}), 3.80-4.20(2 \mathrm{H}, \mathrm{m}), 4.45(2 \mathrm{H}, \mathrm{s}), 5.21(0.7 \mathrm{H}, \mathrm{d}, J=3.5 \mathrm{~Hz}), 5.33(0.3 \mathrm{H}, \mathrm{dd}, J=4,7.5 \mathrm{~Hz}), 6.88(2 \mathrm{H}, \mathrm{d}, J=$ $9 \mathrm{~Hz}), 7.26(2 \mathrm{H}, \mathrm{d}, J=9 \mathrm{~Hz}) . \mathrm{MS} m / z$ (relative intensity): $296\left(\mathrm{M}^{+}, 0.2\right), 278(1.5), 208(2.0), 157(4.1), 137(47), 121$ (100). Exact MS $m / z$ Calcd for $\mathrm{C}_{16} \mathrm{H}_{24} \mathrm{O}_{5}\left(\mathrm{M}^{+}\right)$: 296.1623. Found: 296.1642 .

2,4-Dideoxy-3-O-formyl-5- $O$-(4-methoxybenzyl)-2,4-di- $C$-methyl-L-lyxose (35)_Compound $34 \quad(0.503 \mathrm{~g}$, $1.70 \mathrm{mmol}$ ) was oxidized as described for the preparation of $\mathbf{2 9}$, and purified by chromatography on a silica gel

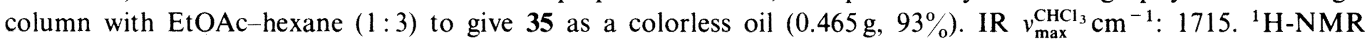
$\left(\mathrm{CDCl}_{3}\right) \delta: 0.95(3 \mathrm{H}, \mathrm{d}, J=7 \mathrm{~Hz}), 1.10(3 \mathrm{H}, \mathrm{d}, J=7 \mathrm{~Hz}), 2.00-2.40(1 \mathrm{H}, \mathrm{m}), 2.74(1 \mathrm{H}, \mathrm{ddq}, J=2.5,7.5,7 \mathrm{~Hz}), 3.27$ $(1 \mathrm{H}, \mathrm{dd}, J=7,10 \mathrm{~Hz}), 3.38(1 \mathrm{H}, \mathrm{dd}, J=5.5,10 \mathrm{~Hz}), 3.81(3 \mathrm{H}, \mathrm{s}), 4.38(2 \mathrm{H}, \mathrm{s}), 5.41(1 \mathrm{H}, \mathrm{ddd}, J=1,5,7.5 \mathrm{~Hz}), 6.89$ $(2 \mathrm{H}, \mathrm{d}, J=9 \mathrm{~Hz}), 7.24(2 \mathrm{H}, \mathrm{d}, J=9 \mathrm{~Hz}), 8.09(1 \mathrm{H}, \mathrm{d}, J=1 \mathrm{~Hz}), 9.63(1 \mathrm{H}, \mathrm{d}, J=2.5 \mathrm{~Hz}) . \mathrm{MS} m / z$ (relative intensity): 294 $\left(\mathrm{M}^{+}, 1.5\right), 190$ (1.3), 175 (1.9), 137 (13), 121 (100). Exact MS $m / z$ Calcd for $\mathrm{C}_{16} \mathrm{H}_{22} \mathrm{O}_{5}\left(\mathrm{M}^{+}\right)$: 294.1467. Found: 294.1480 .

(2Z,4S,5S,6S)-5-Hydroxy-7-O-(4-methoxybenzyl)-2,4,6-trimethylhept-2-enoic Acid $\delta$-Lactone (36) - Compound $35(0.465 \mathrm{~g}, 1.58 \mathrm{mmol})$ was reacted with the sodium salt of $(\mathrm{MeO})_{2} \mathrm{P}(\mathrm{O}) \mathrm{CH}(\mathrm{Me}) \mathrm{CO}_{2} \mathrm{Me}$ as described for the preparation of 30 to give 36 as a colorless oil $(0.392 \mathrm{~g}, 81 \%) .{ }^{1} \mathrm{H}-\mathrm{NMR}\left(\mathrm{CDCl}_{3}\right) \delta: 0.95(3 \mathrm{H}, \mathrm{d}, J=7 \mathrm{~Hz}), 1.05(3 \mathrm{H}, \mathrm{d}$, $J=7 \mathrm{~Hz}), 1.90(3 \mathrm{H}, \mathrm{dd}, J=1.5,2 \mathrm{~Hz}), 2.00-2.15(1 \mathrm{H}, \mathrm{m}), 2.55-2.70(1 \mathrm{H}, \mathrm{m}), 3.40(1 \mathrm{H}, \mathrm{dd}, J=6,9 \mathrm{~Hz}), 3.58(1 \mathrm{H}$, $\mathrm{dd}, J=8.5,9 \mathrm{~Hz}), 3.81(3 \mathrm{H}, \mathrm{s}), 4.24(1 \mathrm{H}, \mathrm{dd}, J=2,11 \mathrm{~Hz}), 4.42(1 \mathrm{H}, \mathrm{d}, J=12 \mathrm{~Hz}), 4.48(1 \mathrm{H}, \mathrm{d}, J=12 \mathrm{~Hz}), 6.34(1 \mathrm{H}$, $\mathrm{dq}, J=1.5,3.5 \mathrm{~Hz}), 6.88(2 \mathrm{H}, \mathrm{d}, J=9 \mathrm{~Hz}), 7.25(2 \mathrm{H}, \mathrm{d}, J=9 \mathrm{~Hz}) . \mathrm{MS} m / z$ (relative intensity): $304\left(\mathrm{M}^{+}, 2.1\right), 289(0.5)$, 217 (5.0), 191 (22), 121 (100). Exact MS $m / z$ Calcd for $\mathrm{C}_{18} \mathrm{H}_{24} \mathrm{O}_{4}\left(\mathrm{M}^{+}\right)$: 304.1674. Found: 304.1684.

$(2 S, 5 S, 6 S)$-2H-5,6-Dihydro-2-isopropyloxy-3,5-dimethyl-6-[1(S)-methyl-2-(4-methoxybenzyloxy)ethyl]pyran (37) Compound $36(0.314 \mathrm{~g}, 1.03 \mathrm{mmol})$ was reduced with DIBAH as described for the reduction of $\mathbf{3 0}$ to give the lactol as a colorless oil $(0.318 \mathrm{~g}, 100 \%) .{ }^{1} \mathrm{H}-\mathrm{NMR}\left(\mathrm{CDCl}_{3}\right) \delta: 0.88(3 \mathrm{H}, \mathrm{d}, J=7 \mathrm{~Hz}), 0.91(3 \mathrm{H}, \mathrm{d}, J=7 \mathrm{~Hz}), 1.73(3 \mathrm{H}, \mathrm{t}$, $J=2 \mathrm{~Hz}), 1.90-2.60(2 \mathrm{H}, \mathrm{m}), 3.34(1 \mathrm{H}, \mathrm{dd}, J=6.5,9 \mathrm{~Hz}), 3.54(1 \mathrm{H}, \mathrm{dd}, J=7.5,9 \mathrm{~Hz}), 3.70(1 \mathrm{H}, \mathrm{dd}, J=2,10.5 \mathrm{~Hz})$, $3.81(3 \mathrm{H}, \mathrm{s}), 4.46(2 \mathrm{H}, \mathrm{s}), 5.09(1 \mathrm{H}, \mathrm{br} \mathrm{s}), 5.44(1 \mathrm{H}, \mathrm{br} \mathrm{s}), 6.90(2 \mathrm{H}, \mathrm{d}, J=9 \mathrm{~Hz}), 7.26(2 \mathrm{H}, \mathrm{d}, J=9 \mathrm{~Hz}) . \mathrm{MS} m / z$ (relative intensity): $306\left(\mathrm{M}^{+}, 0.15\right), 288(1.1), 167(20), 152(8), 137$ (23), 121 (100), 99 (33). Exact MS $m / z$ Calcd for $\mathrm{C}_{18} \mathrm{H}_{26} \mathrm{O}_{4}$ $\left(\mathrm{M}^{+}\right)$: 306.1831. Found: 306.1846. 
The above lactol $(0.31 \mathrm{~g}, 0.89 \mathrm{mmol})$ was treated with iso-PrOH in the presence of CSA as described for the preparation of 31 to afford 37 as a colorless oil $(0.341 \mathrm{~g}, 98 \%) .{ }^{1} \mathrm{H}-\mathrm{NMR}\left(\mathrm{CDCl}_{3}\right) \delta: 0.91(3 \mathrm{H}, \mathrm{d}, J=7 \mathrm{~Hz}), 0.93(3 \mathrm{H}$, $\mathrm{d}, J=7 \mathrm{~Hz}), 1.16(3 \mathrm{H}, \mathrm{d}, J=6 \mathrm{~Hz}), 1.19(3 \mathrm{H}, \mathrm{d}, J=6 \mathrm{~Hz}), 1.67(3 \mathrm{H}, \mathrm{t}, J=1.5 \mathrm{~Hz}), 1.80-2.50(2 \mathrm{H}, \mathrm{m}), 3.39(1 \mathrm{H}, \mathrm{dd}$, $J=7.5,9 \mathrm{~Hz}), 3.56(1 \mathrm{H}, \mathrm{dd}, J=6,9 \mathrm{~Hz}), 3.64(1 \mathrm{H}, \mathrm{dd}, J=2,10 \mathrm{~Hz}), 3.80(3 \mathrm{H}, \mathrm{s}), 3.94(1 \mathrm{H}, \mathrm{sept}, J=6 \mathrm{~Hz}), 4.39(1 \mathrm{H}, \mathrm{d}$, $J=12 \mathrm{~Hz}), 4.52(1 \mathrm{H}, \mathrm{d}, J=12 \mathrm{~Hz}), 4.78(1 \mathrm{H}, \mathrm{br} \mathrm{s}), 5.42(1 \mathrm{H}, \mathrm{br} \mathrm{s}), 6.86(2 \mathrm{H}, \mathrm{d}, J=9 \mathrm{~Hz}), 7.28(2 \mathrm{H}, \mathrm{d}, J=9 \mathrm{~Hz}) . \mathrm{MS}$ $m / z$ (relative intensity): $348\left(\mathrm{M}^{+}, 0.4\right), 305(1.3), 288(0.5), 227(0.8), 167(19), 121$ (100). Exact MS $m / z$ Calcd for $\mathrm{C}_{21} \mathrm{H}_{32} \mathrm{O}_{4}\left(\mathrm{M}^{+}\right): 348.2300$. Found: 348.2283 .

$(\mathbf{R}, 4 S, 5 S, 6 S)-3,4,6-T$ rimethyl-2,9-dioxabicyclo[3.3.1]nonan-7-ene (39) and Its Dimer (40)_-DDQ (0.197g $0.868 \mathrm{mmol})$ was added to a stirred solution of $37(0.252 \mathrm{~g}, 0.724 \mathrm{mmol})$ in $\mathrm{CH}_{2} \mathrm{Cl}_{2}(20 \mathrm{ml})$ and water $(1 \mathrm{ml})$ at room temperature. After $1.5 \mathrm{~h}$, the reaction mixture was diluted with $\mathrm{CH}_{2} \mathrm{Cl}_{2}$, washed with saturated $\mathrm{NaHCO}_{3}$, dried $\left(\mathrm{MgSO}_{4}\right)$, and evaporated in vacuo. The residue was chromatographed on a silica gel column with hexane-EtOAc $(4: 1)$ to give 40 as a colorless oil $(41.5 \mathrm{mg}, 34 \%)$ from the first fraction. ${ }^{1} \mathrm{H}-\mathrm{NMR}\left(\mathrm{CDCl}_{3}\right) \delta: 0.83(6 \mathrm{H}, \mathrm{d}, J=7 \mathrm{~Hz})$, $0.90(6 \mathrm{H}, \mathrm{d}, J=7 \mathrm{~Hz}), 1.68(6 \mathrm{H}, \mathrm{t}, J=2 \mathrm{~Hz}), 1.96-2.40(4 \mathrm{H}, \mathrm{m}), 3.26(2 \mathrm{H}, \mathrm{dd}, J=3,4 \mathrm{~Hz}), 3.84(2 \mathrm{H}, \mathrm{dd}, J=2,11 \mathrm{~Hz})$, $4.07(2 \mathrm{H}, \mathrm{dd}, J=8,11 \mathrm{~Hz}), 4.68(2 \mathrm{H}, \mathrm{s}), 5.43(2 \mathrm{H}, \mathrm{s}) . \mathrm{MS} m / z$ (relative intensity): $336\left(\mathrm{M}^{+}, 45\right), 254(26), 167(31), 123$ (65), 109 (100). Exact MS $m / z$ Calcd for $\mathrm{C}_{20} \mathrm{H}_{32} \mathrm{O}_{4}\left(\mathrm{M}^{+}\right): 336.2300$. Found: 336.2283 .

The second fraction gave 39 as a colorless oil $(58.6 \mathrm{mg}, 48 \%) .{ }^{1} \mathrm{H}-\mathrm{NMR}\left(\mathrm{CDCl}_{3}\right) \delta: 0.73(3 \mathrm{H}, \mathrm{d}, J=7 \mathrm{~Hz}), 1.09$ $(3 \mathrm{H}, \mathrm{d}, J=7 \mathrm{~Hz}), 1.65(3 \mathrm{H}, \mathrm{t}, J=1.5 \mathrm{~Hz}), 2.00-2.30(1 \mathrm{H}, \mathrm{m}), 2.32-2.60(3 \mathrm{H}, \mathrm{m}), 3.50(1 \mathrm{H}, \mathrm{d}, J=11 \mathrm{~Hz}), 3.60(1 \mathrm{H}, \mathrm{d}$, $J=11 \mathrm{~Hz}), 3.63(1 \mathrm{H}, \mathrm{dd}, J=5,12 \mathrm{~Hz}), 6.68-6.80(1 \mathrm{H}, \mathrm{m}) . \mathrm{MS} m / z$ (relative intensity): $168\left(\mathrm{M}^{+}, 15\right), 119(25), 98(22)$, $86(65), 84(100)$.

(2S,5S,6S)-2H-5,6-Dihydro-2-isopropyloxy-3,5-dimethyl-6-[1(S)-methyl-2-hydroxyethyl]pyran (38)-DDQ ( $16 \mathrm{mg}, 0.07 \mathrm{mmol}$ ) was added to a $\mathrm{CH}_{2} \mathrm{Cl}_{2}$ solution $(1.0 \mathrm{ml})$ of $37(12 \mathrm{mg}, 0.0344 \mathrm{mmol})$ containing $\mathrm{Me}_{2} \mathrm{CHOH}$ $(0.05 \mathrm{ml})$ and water $(0.05 \mathrm{ml})$ at room temperature. After $2 \mathrm{~h}$, the mixture was diluted with $\mathrm{CH}_{2} \mathrm{Cl}_{2}$, washed with aqueous $\mathrm{NaHCO}_{3}$, dried $\left(\mathrm{MgSO}_{4}\right)$, and evaporated in vacuo to leave an oil, which was purified by TLC on silica gel with hexane-EtOAc $(1: 1)$ to give 38 as a colorless oil $(6.1 \mathrm{mg}, 78 \%) .{ }^{1} \mathrm{H}-\mathrm{NMR}\left(\mathrm{CDCl}_{3}\right) \delta: 0.90(3 \mathrm{H}, \mathrm{d}, J=7 \mathrm{~Hz}), 0.98$ $(3 \mathrm{H}, \mathrm{d}, J=7 \mathrm{~Hz}), 1.18(3 \mathrm{H}, \mathrm{d}, J=6 \mathrm{~Hz}), 1.26(3 \mathrm{H}, \mathrm{d}, J=6 \mathrm{~Hz}), 1.58(1 \mathrm{H}, \mathrm{br} \mathrm{s}), 1.68(3 \mathrm{H}, \mathrm{t}, J=2 \mathrm{~Hz}), 1.80-2.10(1 \mathrm{H}$, $\mathrm{m}), 2.10-2.44(1 \mathrm{H}, \mathrm{m}), 3.70(1 \mathrm{H}, \mathrm{dd}, J=2,10 \mathrm{~Hz}), 3.82(1 \mathrm{H}, \mathrm{d}, J=10 \mathrm{~Hz}), 3.94(1 \mathrm{H}$, septet, $J=6 \mathrm{~Hz}), 4.80(1 \mathrm{H}, \mathrm{s})$, 5.44 ( $1 \mathrm{H}$, br s). MS $m / z$ (relative intensity): $228\left(\mathrm{M}^{+}, 0.3\right), 169(20), 140(28), 109(40), 98(100)$. Exact MS $m / z$ Calcd for $\mathrm{C}_{10} \mathrm{H}_{17} \mathrm{O}_{2}\left(\mathrm{M}^{+}-59\right)$ : 169.1228 . Found: 169.1232 .

\section{References and Notes}

1) Chiral Synthesis of Polyketide-Derived Natural Products. XI. For part X, see: N. Nakajima, T. Hamada, T. Tanaka, Y. Oikawa, and O. Yonemitsu, J. Am. Chem. Soc., 108, 4645 (1986).

2) A preliminary report of this work: Y. Oikawa, T. Tanaka, and O. Yonemitsu, Tetrahedron Lett., 27, 3647 (1986).

3) I. Paterson and M. M. Mansuri, Tetrahedron, 41, 3569 (1985).

4) C. Djerassi and J. A. Zderic, J. Am. Chem. Soc., 78, 2907, 6390 (1956).

5) a) H. Brockmann and W. Henkel, Naturwissenschaften, 37, $138(1950)$; b) Idem, Chem. Ber., 84, $284(1951)$; c) H. Muxfeld, S. Shrader, P. Hansen, and H. Brockmann, J. Am. Chem. Soc., 90, 4748 (1986).

6) a) E. J. Corey, P. B. Hopkins, S. Kim, K. P. Nambiar, and J. R. Falck, J. Am. Chem. Soc., 101, 7131 (1979); b) R. B. Woodward, et al., ibid., 103, 3210, 3213, 3215 (1981); c) B. Bernet, P. M. Bishop, M. Caron, T. Kawamata, B. L. Roy, L. Ruest, G. Sauve, P. Soucy, and P. Deslongchamp, Can. J. Chem., 63, 2810, 2814 (1985); d) M Kinoshita, M. Arai, K. Tomioka, and M. Nakata, Tetrahedron Lett., 27, 1811 (1986); e) M. Kinoshita, M. Arai, N. Ohsawa, and M. Nakata, ibid., 27, 1815 (1986).

7) a) K. Tatsuta, Y. Amemiya, Y. Kanemura, and M. Kinoshita, Tetrahedron Lett., 22, 3997 (1981); b) K. Tatsuta, Y. Amemiya, Y. Kanemura, H. Takahashi, and M. Kinoshita, ibid., 23, 3375 (1982); c) K. C. Nicolaou, M. R. Pavia, and S. P. Seitz, J. Am. Chem. Soc., 104, 2027 (1982); d) K. C. Nicolaou, S. P. Seitz, and M. R. Pavia, ibid., 104, 2030 (1982); e) S. Masamune, T. Kaiho, and D. S. Garvey, ibid., 104, 5521 (1982).

8) J. W. Westley, J. F. Flount, R. H. Evans, Jr., A. Stempel, and J. Berger, J. Antibiot., 27, 597 (1974).

9) a) Y. Miyazaki, M. Shibuya, H. Sugawara, O. Kawaguchi, C. Hirose, J. Nagatsu, and S. Esumi, J. Antibiot., 27, 814 (1974); $b$ ) Y. Kishi, S. Hatakeyama, and M. D. Lewis, Front. Chem. Plenary Keynote Lect. 28th IUPAC Congr., 1981; ed. by K. J. Laidler, Pergamon Press, Oxford, 1982, p. 287.

10) K. Horita, T. Yoshioka, T. Tanaka, Y. Oikawa, and O. Yonemitsu, Tetrahedron, 42, 3021 (1986), and references cited therein.

11) a) S. Masamune, C. U. Kim, K. E. Wilson, G. O. Spessard, P. E. Giorghiou, and G. S. Bates, J. Am. Chem. Soc., 97, 3512 (1975); b) S. Masamune, H. Yamamoto, S. Kamata, and A. Fukazawa, ibid., 97, 3513 (1975); c) P. A. Grieco, Y. Ohfune, Y. Yokoyama, and W. Owens, ibid., 101, 4749 (1979); d) A. Nakano, S. Takimoto, J. Inanaga, T. Katsuki, S. Ouchida, K. Inoue, M. Aiga, N. Okakado, and M. Yamaguchi, Chem. Lett., 1979, 1019; e) J. Inanaga, T. Katsuki, S. Takimoto, S. Ouchida, K. Inoue, A. Nakano, N. Okukado, and M. Yamaguchi, ibid., 1979, 1021; f) R. E. Ireland and J. P. Daub, J. Org. Chem., 46, 479 (1981); idem, ibid., 48, 1303 (1983); g) 
R. E. Ireland, J. P. Daub, G. S. Mandel, and N. S. Mandel, ibid., 48, 1312 (1983).

12) Syntheses of optically active Prelog-Djerassi lactonic acid $a$ ) P. A. Grieco, Y. Ohfune, Y. Yokoyama, and W. Owens, J. Am. Chem. Soc., 101, 4749 (1979); b) S. Jarosz and B. Fraser-Reid, Tetrahedron Lett., 22, 2533 (1981); c) M. Isobe, Y. Ichikawa, and T. Goto, ibid., 22, 4287 (1981); d) P. Bartlett and J. L. Adams, J. Am. Chem. Soc., 102, 337 (1980); e) D. A. Evans and J. Bartroli, Tetrahedron Lett., 23, 807 (1982); f) S. Masamune, M. Hirama, S. Mori, S. A. Ali, and D. S. Garvey, J. Am. Chem. Soc., 103, 1568 (1981); g) S. F. Martin and D. E. Guinn, Tetrahedron Lett., 25, 5607 (1984); h) D. J.-S. Tsai and M. M. Midland, J. Am. Chem. Soc., 107, 3915 ( (985); i) R. W. Hoffmann, M.-J. Zeib, W. Ladner, and S. Tabche, Chem. Ber., 115, 2357 (1982).

13) A. Rosenthal and M. Sprinzl, Can. J. Chem., 47, 3941 (1969).

14) W. C. Still and J. C. Barrish, J. Am. Chem. Soc., 105, 2487 (1983).

15) K. N. Houk, N. G. Rondan, Y.-D. Wu, J. T. Metz, and M. N. Paddon-Row, Tetrahedron, 40, 2257 (1984).

16) Cf. T. Nakata, G. Schmid, B. Vranesic, M. Okigawa, T. Smith-Palmer, and Y. Kishi, J. Am. Chem. Soc., 100, 2933 (1978).

In contrast with the $C-3-\alpha$-methyl compounds $(\mathbf{1 2}, \mathbf{1 4}, \mathbf{1 6})$, the corresponding $C-3-\beta$-methyl compounds $(\mathbf{2 2}, \mathbf{2 3}$, 24) showed rather opposite stereoselectivities in the formation of the hydroxy compounds (25a, b, 26a, b, 27a, b), probably because of steric repulsion between methyl groups in the transition structure (M-2) in Chart 3 . The results are also shown in Table I. Details will be reported elsewhere.

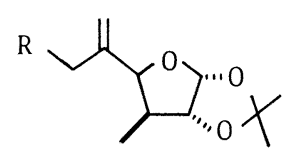

$22: \mathrm{R}=\mathrm{H}$

$23: \mathrm{R}=\mathrm{OBn}$

$24: \mathrm{R}=\mathrm{OS} \mathrm{i}+\mathrm{T}$

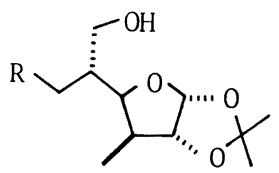

25a: $\mathrm{R}=\mathrm{H}$

26a : $\mathrm{R}=\mathrm{OBn}$

27a: $\mathrm{R}=\mathrm{OSi} \mp$

Chart 5<smiles>[R]CC(CO)C1O[C@@H]2OC(C)(C)O[C@@H]2C1C</smiles>

$25 \mathrm{~b}: \mathrm{R}=\mathrm{H}$

26b : $\mathrm{R}=\mathrm{OBn}$

$27 \mathrm{~b}: \mathrm{R}=\mathrm{OSi} \mp$

17) a) J. Boutagy and R. Thomas, Chem. Rev., 74, 87 (1974); b) G. Schmid, T. Fukuyama, K. Akasaka, and Y. Kishi, J. Am. Chem. Soc., 101, 259 (1979).

18) a) R. H. Schlessinger and M. A. Poss, J. Am. Chem. Soc., 104, 357 (1982); b) S. Danishefsky, N. Kata, D. Askin, and J. F. Kerwin, Jr., ibid., 104, 360 (1982).

19) Y. Oikawa, T. Tanaka, K. Horita, and O. Yonemitsu, Tetrahedron Lett., 25, 5397 (1984).

20) When 37 was treated with DDQ under usual conditions for deprotection of MPM groups in dichloromethane containing a small amount of water, ${ }^{10.211}$ a mixture of $\mathbf{3 9}$ and $\mathbf{4 0}$ instead of the desired $\mathbf{3 8}$ was obtained because the isopropyl protection of $\mathbf{3 8}$ was labile even to very weak acids. This disadvantage was overcome by the addition of isopropanol.

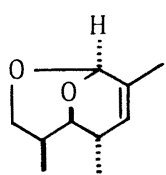

39

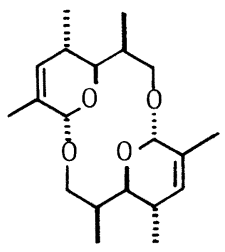

40

Chart 6

21) Y. Oikawa, T. Yoshioka, and O. Yonemitsu, Tetrahedron Lett., 23, 885 (1982). 